\title{
Solubility Testing of Actinides on Breathing-Zone and Area Air Samples
}

Manuscript Completed: December 1995

Date Published: February 1996

Prepared by

R. L. Metzger, B. H. Jessop, B. L. McDowell

Radiation Safety Engineering, Inc.

3245 North Washington Street

Chandler, AZ 85225

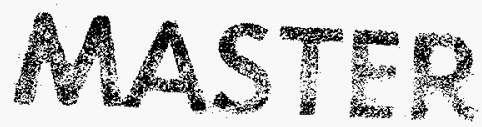

S. McGuire, NRC Project Manager

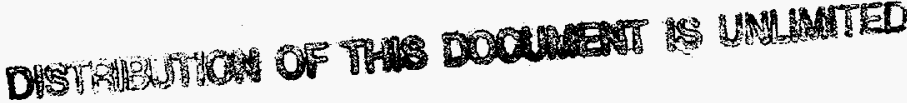

Prepared for

Division of Regulatory Applications

Office of Nuclear Regulatory Research

U.S. Nuclear Regulatory Commission

Washington, DC 20555-0001

NRC Job Code W6123 


\section{DISCLAMMER}

Portions of this document may be illegible in electronic image products. Images are produced from the best available original document. 


\begin{abstract}
A solubility testing method for several common actinides has been developed with sufficient sensitivity to allow profiles to be determined from routine breathing zone and area air samples in the workplace. Air samples are covered with a clean filter to form a filter-sample-filter sandwich which is immersed in an extracellular lung serum simulant solution. The sample is moved to a fresh beaker of the lung fluid simulant each day for one week, and then weekly until the end of the 28 day test period. The soak solutions are wet ashed with nitric acid and hydrogen peroxide to destroy the organic components of the lung simulant solution prior to extraction of the nuclides of interest directly into an extractive scintillator for subsequent counting on a PhotonElectron Rejecting Alpha Liquid Scintillation (PERALS ${ }^{\circledR}$ ) spectrometer. Solvent extraction methods utilizing the extractive scintillators have been developed for the isotopes of uranium, plutonium, and curium. The procedures normally produce an isotopic recovery greater than $95 \%$ and have been used to develop solubility profiles from air samples with $40 \mathrm{pCi}$ or less of $\mathrm{U}_{3} \mathrm{O}_{8}$. Profiles developed for $\mathrm{U}_{3} \mathrm{O}_{8}$ samples show good agreement with in vitro and in vivo tests performed by other investigators on samples from the same uranium mills.
\end{abstract}




\section{Contents}

Abstract

iii

Contents

v

Figures and Tables

vi

1. Introduction

Page 1

$1.1 \quad$ Background

Page 1

2. Approach

Page 2

3. Methods

Page 3

3.1.1. The Solubility Test

Page 4

3.2.1. Sample Preparation - Gamble's Solution

Page 4

3.2.2. Sample Preparation - Filter Media

Page 5

3.3.1. The Extraction of Uranium

Page 5

3.3.2. The Alphaex Extraction of Uranium

Page 5

3.3.3. An Alphaex Extraction After Chelation

Page 6

3.3.4. Uranium by Tertiary Amine Solvent Extraction

Page 7

3.4.1. The Extraction of Plutonium Isotopes

Page 7

3.5.1. The Extraction of Curium Isotopes

Page 7

3.6.1. The Extraction of Plutonium, Curium, and Uranium by Sequential Solvent Extraction

Page 8

Page 9

4. Intercomparison Methods

Page 10

4.1. Solubility Class and Dosimetry Intercomparisons

Page 11

5. Inorganic Lung Simulant Solutions

Page 12

5.1.1. Extraction of Uranium from the Simple Lung Fluid Simulants

Page 12

5.1.2. The Solubility Test

Page 14

6. Conclusion

Page 14

References

Page 18

Appendix 
Figures

Figure 3.1a. Alphaex extraction of EPA cross-check sample, containing

Page 6 natural $\mathrm{U},{ }^{26} \mathrm{Ra},{ }^{228} \mathrm{Ra}$ and their daughters.

Figure 3.1b. Alphaex extraction of same EPA cross-check sample, after addition of DTPA to the aqueous phase.

Page 6

Figure 3.2. The distribution of curium from an aqueous solution $1 \mathrm{M}$ in $\mathrm{Al}\left(\mathrm{NO}_{3}\right)_{3}$ to a $0.4 M C M P O$ extractive scintillator as a function of nitric acid

Page 8 concentration.

Figure 3.3. The distribution of curium and uranium from an aqueous solution $1 M$ in $\mathrm{Al}\left(\mathrm{NO}_{3}\right)_{3}$ to a $0.4 \mathrm{M} \mathrm{CMPO}$ plus $0.2 \mathrm{M} \mathrm{HDEHP}$ extractive scintillator as a function of nitric acid concentration.

Figure 4.1. Solubility profiles of ITRI $\mathrm{U}_{3} \mathrm{O}_{3}$ samples from same mill as those analyzed by Eidson and Damon.

Figure 5.1. Solubility of a $\mathrm{U}_{3} \mathrm{O}_{8}$ sample using Gamble's solution and simple lung simulants.

Page 10

Page 13

Tables

Table 1.1. Composition of Simulated Serum Ultrafiltrate

Page 2

Table 2.1. Extractive Scintillators

Page 3

Table 3.1. Common Isotopes of Plutonium, Curium, and Uranium and their Alpha

Page 9

Emissions

Table 4.1. Intercomparison of Solubility Tests on $\mathrm{U}_{3} \mathrm{O}_{8}$ Samples

Page 11

Table 4.2. Intercomparison of Estimated Doses from an Acute Inhalation Dose of $2 \mathrm{nCi}$ of the $\mathrm{U}_{3} \mathrm{O}_{8}$ Compounds Described in Table 4.1 Above

Page 11 (AMAD - $1 \mu$ )

Table 5.1. Simple Lung Fluid Solvent Test on a $\mathrm{U}_{3} \mathrm{O}_{8}$ Sample

Page 13 


\section{FOREWORD}

The NRC's regulations in 10 CFR Part 20, "Standards for Protection against Radiation," contain an Appendix B that lists the annual limit on intake by inhalation for radionuclides. The annual limits on intake are given for three classes of solubility of the radionuclides in the lung. Therefore, licensees will sometimes need to determine the solubility of airborne radionuclides collected by air sampling in order to determine worker doses and to demonstrate compliance with the dose limits in 10 CFR Part 20. This report describes research into a simple method to determine the solubility of airborne radionuclides.

However, NUREG reports are not substitutes for NRC regulations, and compliance with the methods described in NUREG reports is not required. The approaches and methods in this report are provided for information only. Publication of this report does not necessarily constitute NRC approval or agreement with the information contained herein.

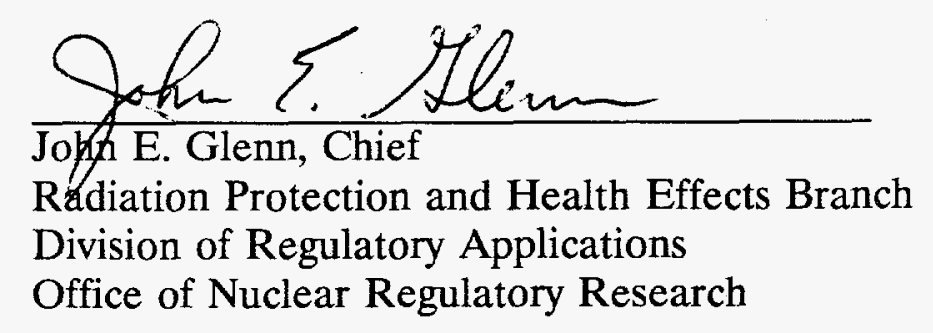




\section{Introduction.}

1.1. Background. The determination of radiation dose resulting from inhaled radionuclides is dependent on the radioisotopes and activity present in the dust, the particle size distribution, and the solubility of the dust in the human lung. The clearance rates from the lung have been classified by the International Commission on Radiological Protection in its report No. 30 (ICRP 1979) into three classes: Class D for nuclides with clearance half times less than 10 days, Class W for clearance half times from 10 to 100 days, and Class $Y$ for insoluble forms with clearance rates in excess of 100 days. Actual clearance of radioactive aerosols from the lung is a complex process dependent on both physical and chemical factors relating to the dust and lung kinetics. Dissolution and transport are the principle methods of lung clearance. Most particles are first deposited on extracellular airway lining fluid which has a $\mathrm{pH}$ of approximately 7.3, and contains proteins, lipids, and both organic and inorganic salts. Within one day, essentially all undissolved particles are phagocytized by macrophages in the airways and alveoli. The particles are then held in an intracellular organelle (phagolysosome) with a pH of 4.5 to 5.5 (Guilmette 1995). Compounds that dissolve in the phagolysosome may be released to the blood immediately or may be avidly held until cell death. While it is known that this intracellular microenvironment plays a significant role in dissolution of inhaled radionuclides, a good in vitro model of this environment has not been developed. Most in vitro test methods to determine solubility profiles seek to imitate the initial lung surfactant fluid. Gamble's solution (Table 1.1), originally developed in 1942, is a widely used simulant which has shown reasonable correlation with in vivo solubility profiles of uranium in rodents (Damon 1984). Other investigators (Henge-Napoli 1989) have suggested that simple carbonate or phosphate solutions without organic components will also produce reasonable solubility profiles for many compounds. Typically, a sample of the compound to be tested is collected and is sealed between two membrane filters to form a filter sandwich. This sandwich is submersed in the lung surfactant simulant solution and is changed frequently during the first day, daily for the remainder of the first week, and weekly until the end of the 30 day test period. The amount of the radionuclide dissolved in the lung fluid simulant is determined either by direct counting for gamma emitters or by separation chemistry and counting on proportional counters or surface barrier detectors for alpha emitting radionuclides. At the end of the test, the filter is destroyed and the remaining nuclides that did not dissolve in the test period are determined. The dissolution data is then fitted to a three element exponential model (Equation 1) which defines the dissolution fractions and half times.

$$
\% \text { undissolved }=A_{1} e^{-\lambda_{1} t}+A_{2} e^{-\lambda_{2} t}+A_{3} e^{-\lambda_{3} t}
$$

All solubility testing has been conducted thus far in a research setting on bulk samples of specific compounds. No standardized method has evolved, and no routine solubility testing of nuclide compounds commonly found in the workplace has been conducted. This research has centered on the development of test methods for determining the 
solubility profiles of radionuclides that are present in the workplace or environment using breathing zone or other air samples collected in these locations. The work has centered on uranium and transuranic radionuclides, as these have the highest radiotoxicity and frequently have complex solubility profiles.

Table 1.1 Composition of Simulated Serum Ultrafiltrate (Eidson 1983)

\begin{tabular}{||l|l||}
\hline Salt & $\begin{array}{l}\text { Molar } \\
\text { Concentration }\end{array}$ \\
\hline $\mathrm{NaCl}$ & 0.116 \\
\hline $\mathrm{NH}_{4} \mathrm{Cl}$ & 0.010 \\
\hline $\mathrm{NaHCO}_{3}$ & 0.027 \\
\hline Glycine & 0.005 \\
\hline $\mathrm{Na}_{3}$ Citrate & 0.0002 \\
\hline $\mathrm{CaCl}_{2}$ & 0.0002 \\
\hline${\mathrm{L}-\mathrm{Cysteine}}$ & 0.001 \\
\hline $\mathrm{H}_{2} \mathrm{SO}_{4}$ & 0.0005 \\
\hline $\mathrm{NaH}_{2} \mathrm{PO}_{4}$ & 0.0012 \\
\hline $\mathrm{DTPA}^{\mathrm{a}}$ & 0.0002 \\
\hline $\mathrm{ABAC}^{\mathrm{b}}$ & $50 \mathrm{ppm}$ \\
\hline
\end{tabular}

'Diethylenetriaminepentaacetic acid, not present in blood serum.

${ }^{b}$ Alkylbenzyldimethylammonium chloride added as an antibacterial agent.

\section{Approach.}

The Derived Air Concentration (DAC) of actinides ranges from $6 \times 10^{-10} \mu \mathrm{Ci} / \mathrm{mL}$ for soluble forms of uranium to $3 \times 10^{-12} \mu \mathrm{Ci} / \mathrm{mL}$ for insoluble oxides of plutonium. Since most workplaces maintain air concentrations at a small fraction of the allowable limits, the determination of solubility profiles from workplace air samples requires a separation procedure with a high recovery of sample nuclides and a counting system with a high counting efficiency and a low background. Based on these considerations, the PhotonElectron Rejecting Alpha Liquid Scintillation (PERALS $\left.{ }^{\mathbb{B}}\right)^{1}$ spectrometer was chosen for this work. The PERALS system uses pulse shape discrimination to isolate longer pulses resulting from alpha interactions from those resulting from $\beta-\gamma$ interactions in the TN 37830 .

${ }^{1}$ PERALS spectrometer is manufactured by ORDELA, Inc., 1009 Alvin Weinberg Dr., Oak Ridge, 
scintillation cocktail. A timing circuit and gate is used to reject the $\beta-\gamma$ pulses and the alpha pulses are sent to a multichannel analyzer for pulse height analysis and display of the energy spectrum. The counter typically has a background of 0.01 counts per minute under an alpha peak, and an alpha counting efficiency of $>99$ percent. Energy resolution is about $220 \mathrm{keV}$ full width at half maximum for a $5 \mathrm{MeV}$ alpha source and the lower limit of detection for a one hour count is typically 0.07 to $0.10 \mathrm{pCi}$.

The PERALS spectrometer further allows the use of extractive scintillators. Like traditional liquid scintillators, these contain a fluor, an energy conducting medium, and an organic solvent. In addition, the extractive scintillators contain an organophilic metal ion extractant that allows the direct phase transfer of a radionuclide(s) into the scintillator from an aqueous solution. A list of the extractive scintillators used in this work is presented in Table 2.1.

Table 2.1 Extractive Scintillators ${ }^{2}$

\begin{tabular}{||c|c|c|c|c||}
\hline Product & $\begin{array}{c}\text { Nuclides } \\
\text { Extracted }\end{array}$ & $\begin{array}{c}\text { Aqueous } \\
\text { System }\end{array}$ & Extractant & Normal pH \\
\hline ALPHAEX & $\begin{array}{c}\text { Actinides } \\
\text { (III, IV, \& VI) }\end{array}$ & $\begin{array}{c}\text { Acid } \\
\left(\mathrm{HNO}_{3} \text { or }\right. \\
\mathrm{HCl})\end{array}$ & $\begin{array}{c}\text { bis(2-ethylhexyl) } \\
\text { hydrogen } \\
\text { phosphate }\end{array}$ & $2-3$ \\
\hline URAEX $^{\circledR}$ & Uranium & $\begin{array}{c}\mathrm{Acid} \\
\left(\mathrm{H}_{2} \mathrm{SO}_{4}\right)\end{array}$ & tri-octyl amine & $0.5-1.5$ \\
\hline THOREX $^{\circledR}$ & $\begin{array}{c}\text { Th, Pu \& } \\
\text { other } \\
\text { actinides }\end{array}$ & $\begin{array}{c}\mathrm{Acid}_{2} \\
\left(\mathrm{H}_{2} \mathrm{SO}_{4}\right)\end{array}$ & Primene JMT & $0.5-1.5$ \\
\hline $\begin{array}{c}\text { CMPO } \\
\text { Scintillator }\end{array}$ & $\begin{array}{c}\text { Cm, Am \& } \\
\text { other } \\
\text { transuranics }\end{array}$ & $\begin{array}{c}\text { Acid } \\
\left(\mathrm{HNO}_{3}\right)\end{array}$ & $\begin{array}{c}\text { octyl(phenyl)-N,N- } \\
\text { diisobutyl } \\
\text { carbamoylmethyl- } \\
\text { phosphine oxide }\end{array}$ & $1.0-1.5$ \\
\hline
\end{tabular}

A solubility testing method with sufficient sensitivity to perform tests on routine breathing zone and medium volume air samples collected in the workplace has been developed based on straightforward solvent extraction chemistry methods utilizing extractive scintillators and PERALS spectroscopy.

3. Methods. Since the determination of a solubility profile requires at least 11 separations on each sample over the course of a month, the methods presented below

\footnotetext{
${ }^{2}$ The extractive scintillators are manufactured by ETRAC, Inc., 1009 Alvin Weinberg Dr., Oak Ridge, TN 37830.
} 
have been developed with the goals of simplicity and high nuclide recovery ( $>95 \%$ ). Lengthy procedures increase the probability of a lab error resulting in the loss of the sample or data and also increase the cost of performing the analysis. Where possible, the nuclides of interest have been phase transferred to the extractive scintillator in one step, making it possible for a relatively inexperienced laboratory technician to perform the separation in a short period of time with a high degree of success. Each procedure is presented in its entirety in the Appendix to this report and is discussed below.

3.1.1. The Solubility Test. The solubility test is performed by conducting an air sample in an area where some airborne compound of interest is known to exist using a 0.4 or 0.8 micron Gelman GN4 filter in a standard $37 \mathrm{~mm}$ breathing zone cassette. The amount of activity on the filter at the completion of the test should be 40 $\mathrm{pCi}$ or greater, although solubility profiles have been successfully developed with as little as $10 \mathrm{pCi}$. A low volume breathing zone air pump mounted on a worker's belt or a medium volume pump may be used. After the sample is completed, the filter should be removed from the cassette and covered with a clean filter of the same type to form a filter-sample-filter sandwich. This sandwich is held together using two plastic center sections of a standard three part air sampling cassette. The plastic rings should be squeezed together tightly and taped to ensure that the assembly holds together for the duration of the 28 day test. This filter sandwich is then immersed in a beaker holding $90 \mathrm{~mL}$ of Gamble's solution, which is maintained at a $\mathrm{pH}$ of 7.2 by keeping it under carbon dioxide gas. The filter sandwich is moved to a fresh beaker of Gambles' solution each day for the first week, and then weekly until the end of the 28 day test period. After each change, the old Gamble's solution is wet ashed and the nuclides of interest are extracted using the procedures described below, or other equivalent separation chemistry methods. At the completion of the soak test, the filter assembly is taken apart and the filter sandwich with the insoluble dusts that have not gone into solution during the 28 day test period are dissolved in concentrated acids prior to extraction of the nuclides of interest. Great care must be taken to ensure that all of the insoluble dusts are in solution prior to the start of the extraction chemistry. When the test is complete, the total activity on the filter is determined and the percent undissolved at each stage is calculated. This data is fit to the three exponential equation shown in Equation 1 above using an appropriate non-linear curve fitting algorithm. This fitted equation is then used to calculate the fraction of the nuclide that dissolved within 10 days (Class D), between 10 and 100 days (Class $W$ ), and greater than 100 days (Class $Y$ ).

3.2.1. Sample Preparation - Gamble's Solution. The Gamble's solution is wet ashed to destroy and drive off the organic components that can interfere with the solvent extraction of the radionuclides. Each sample is treated with three 10-mL additions of concentrated nitric acid, and four or five 3-mL additions of $30 \%$ hydrogen peroxide, while being evaporated on a hot plate. After the organic constituents have been destroyed, the sample is evaporated until the inorganic salts precipitate. The sample is then heated gently to near dryness, without baking the salts, and is then set aside to cool. Water is then slowly added to the beaker until the salts redissolve (about 
$30 \mathrm{~mL})$.

3.2.2. Sample Preparation - Filter Media. After tests of numerous filter media (work not shown), the Gelman GN4 filter media was chosen for this work. This membrane filter media is available in pore sizes and diameters commonly used in breathing zone and medium volume air sampling and readily dissolves in concentrated nitric acid, leaving no residue to interfere with the extraction of the nuclides of interest. The filter sandwich, consisting of the two filters and the dusts that had not dissolved into the Gamble's solution over the course of the test, are placed in a Teflon beaker and $10 \mathrm{~mL}$ of concentrated nitric acid is added. The beaker is heated gently until the filter is dissolved completely (about 5 minutes), and then $3 \mathrm{~mL}$ of $30 \%$ hydrogen peroxide is added. Repeated additions of nitric acid and hydrogen peroxide are made until the organic components are driven off and a clear solution remains. If isotopes of plutonium are known to be in the sampled air, or if insoluble silicates are visible in the solution, then additions of hydrofluoric acid must be made until the sample is completely in solution. Breathing zone air samples typically contain $<100 \mathrm{mg}$ of total solids with particle diameters less than 20 microns. Insoluble particles of this diameter may not be visible in the solution, so hydrofluoric acid treatments should be used whenever isotopes of plutonium or thorium are of interest. After the sample has been completely dissolved, the volume is reduced to near dryness, and the beaker is set aside to cool. The side walls of the Teflon ${ }^{8}$ beaker are then washed with nitric acid and the sample is again heated to near dryness to destroy any residual hydrofluoric acid that may be present.

3.3.1. The Extraction of Uranium. Three methods for the extraction of the isotopes of uranium form the Gamble's solution and the filter media have been developed. The first, which is a simple extraction into ALPHAEX, should be used when the only actinide on the air filter is uranium. The ALPHAEX is not specific for uranium and will extract other actinides if they are present. In the second procedure the hydrophyllic chelating agent diethylenetriamine pentaacetic acid (DTPA) complexes other actinides in the aqueous solution, preventing their extraction. DTPA has little affinity for the uranyl ion. Finally, in the third method the aqueous system is changed from nitrate to sulfate by the addition of sulfuric acid and heating to drive off the nitrates. The uranium is then extracted with the extractive scintillator, URAEX. Recovery of the uranium isotopes can be determined using a ${ }^{232} \mathrm{U}$ tracer in each sample, if desired.

3.3.2 The ALPHAEX Extraction of Uranium. If only isotopes of uranium are known to be present in the sample, the uranium may be rapidly and simply phasetransferred to the extractive scintillator ALPHAEX. The volume of the wet ashed sample is brought up to approximately $30 \mathrm{~mL}$ with de-ionized water (DI-water) and the $\mathrm{pH}$ is adjusted to 2 - 3 with $6 \mathrm{M} \mathrm{NaOH}$. If any iron is thought to be present (common in decommissioning activities), $200 \mathrm{mg}$ ascorbic acid is added to the solution, and the sample is transferred to a Teflon separatory funnel or a $50-\mathrm{mL}$ centrifuge tube. One and 
one-half $\mathrm{mL}$ of ALPHAEX is then added to the funnel and the sample is agitated by hand for three to five minutes. The phases are then allowed to separate, or the sample may be centrifuged to speed the separation. One milliliter of the ALPHAEX is drawn off the top of the sample and is placed in a $10 \times 75 \mathrm{~mm}$ culture tube. The scintillator is then sparged with argon for five minutes to drive off oxygen in the scintillator (oxygen will quench the signal), and the sample is counted on the PERALS spectrometer. The time spectrum should be checked for each sample to ensure that the pulse shape discriminator is properly set in the valley between the $\beta-\gamma$ and the alpha pulses. The alpha peaks of interest should be integrated on the multichannel analyzer and the activity in the sample may be determined using the formulae presented after each procedure in the Appendix. After testing this method with eight samples, spiked with a natural uranium standard ${ }^{3}$, the recovery of the uranium in the sample was found to be normally in excess of 97 percent.

3.3.3. An ALPHAEX Extraction After Chelation. The intrinsic resolution of the PERALS spectrometer is relatively poor, with a full width at half maximum of approximately $220 \mathrm{keV}$ for most alpha peaks. Several of the isotopes of thorium in the natural chains have alpha emissions sufficiently close to the energies of the ${ }^{234} U$ and ${ }^{238} U$ that they cannot be separated on the multichannel analyzer. If other actinides are present in the sample (common with ore dust samples), then DTPA may be used to complex the interfering actinides. The procedure is the same as that described in section

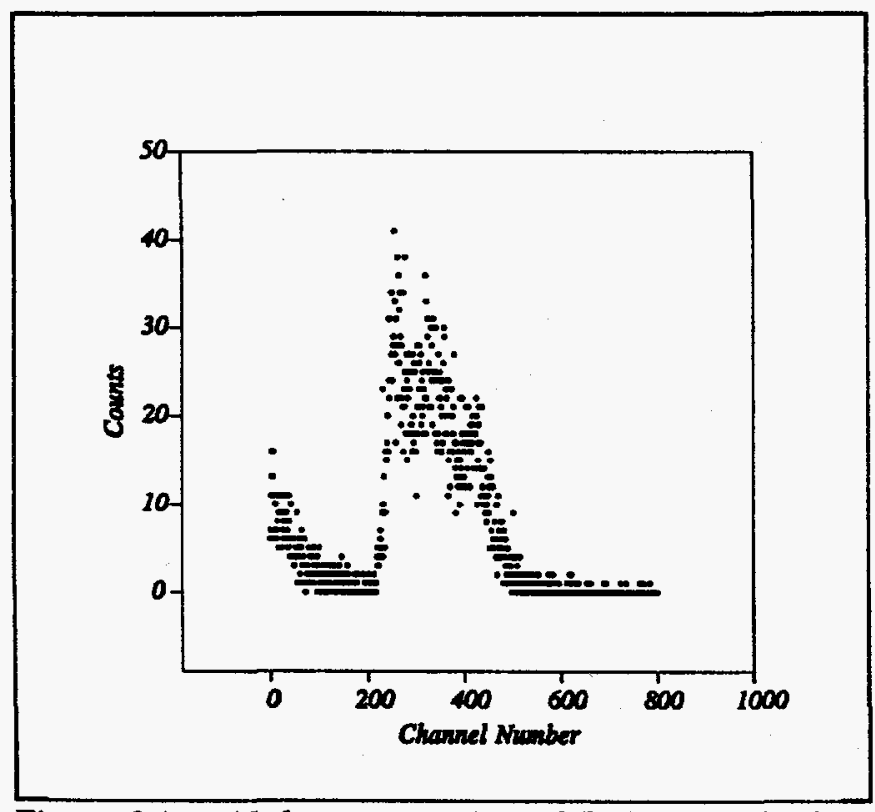

Figure 3.1a. Alphaex extraction of EPA cross-check sample, containing natural $\mathrm{U},{ }^{26} \mathrm{Ra},{ }^{228} \mathrm{Ra}$ and their daughters.

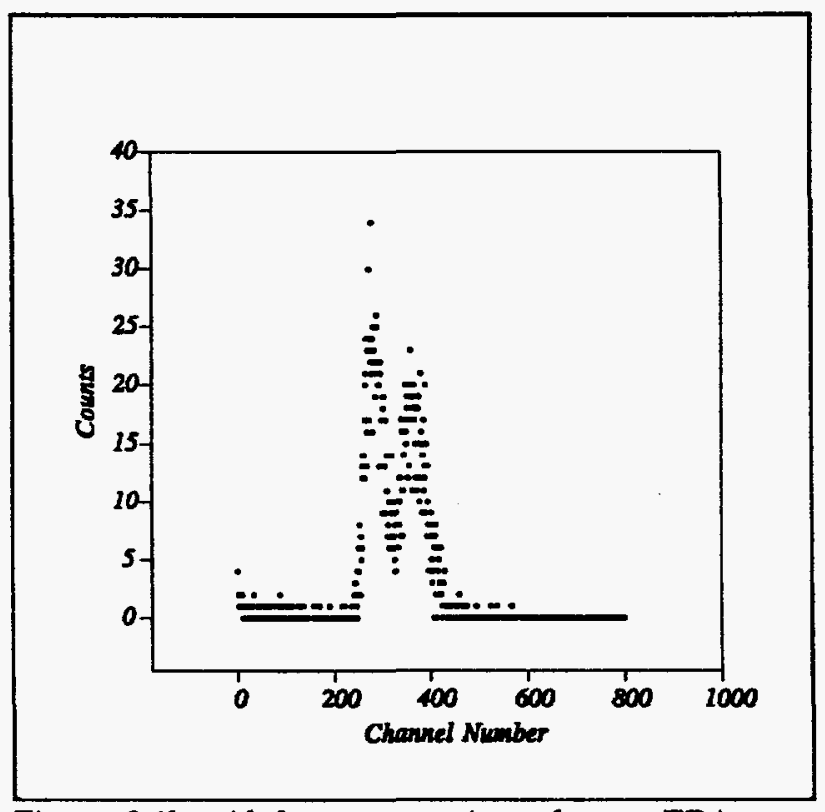

Figure 3.1b. Alphaex extraction of same EPA cross-check sample, after addition of DTPA to the aqueous phase.

${ }^{3}$ EPA Standard Reference Material: \#1843-2; October 1993. United States Environmental Protection Agency, P.O. Box 93478, Las Vegas, NV 89193-3478. 
3.3.2, except the aqueous solution is made $0.01 \mathrm{M}$ in DTPA before the addition of the ascorbic acid. Shown in Figures $3.1 \mathrm{a}$ and $3.1 \mathrm{~b}$ are energy spectra for an EPA uranium/radium cross-check sample containing natural uranium, radium-226, radium228 and all of their attendant daughters. These figures show the effect of the chelating agents.

3.3.4. Uranium Extraction by URAEX. In this method, the aqueous phase is converted from a nitrate system to a sulfate system by the addition of sulfuric acid. The sample is then evaporated to dryness and the temperature of the hot plate is raised to $190{ }^{\circ} \mathrm{C}$ to fume off any remaining nitrates. Approximately $10 \mathrm{~mL}$ of DI-water is slowly added to the beaker to redissolve the salts, and the sample is extracted with URAEX. An internal ${ }^{232} U$ tracer should be used for this procedure to track recovery of the uranium in the sample. The URAEX is fairly specific for uranium; however, some ${ }^{210}$ Po will also be extracted if present in the sample. The alpha emission from ${ }^{210} \mathrm{Po}(5.30$ $\mathrm{MeV}$ ) is sufficiently close to the ${ }^{232} \mathrm{U}$ alpha peak $(5.32 \& 5.27 \mathrm{MeV})$ that they cannot be resolved. If ${ }^{210} \mathrm{Po}$ is present in the sample, this method will produce a biased recovery estimate. This method, tested by spiking seven samples with a natural uranium standard ${ }^{3}$, shows that recovery normally exceeds 95 percent. However, caution must be used to ensure that uranium is not baked onto the sidewalls of the beaker during the conversion to the sulfate system.

3.4.1. The Extraction of Plutonium Isotopes. A highly specific method for plutonium requires a dual extraction to isolate the plutonium isotopes from other nuclides. The plutonium is first extracted from a saturated nitrate aqueous solution into a tri-n-octyl amine solution (not an extractive scintillator). This organic phase is washed with a $0.7 \mathrm{M} \mathrm{HNO}_{3}$ to remove any uranium or iron that may have been co-extracted. The plutonium is then stripped from the organic solution with three washes of a sulfuric acid/sodium sulfate solution. The aqueous strip solution, which now only contains isotopes of plutonium, is extracted with THOREX. Even though two extractions are necessary to achieve specificity for plutonium, the distribution coefficients for the extractions are sufficiently high that recovery of plutonium is normally 94 to 97 percent. This recovery is based upon ten samples that were spiked with either ${ }^{240} \mathrm{Pu}$ standard ${ }^{4}$ or ${ }^{242} \mathrm{Pu}$ standard ${ }^{5}$, or both. The recovery may be traced with a ${ }^{236} \mathrm{Pu}$ standard solution.

3.5.1. The Extraction of Curium Isotopes. Extraction tests made on eighteen solutions spiked with ${ }^{244} \mathrm{Cm}$ standards ${ }^{6}$, using all commercially available extractive

${ }^{4}$ EPA Standard Reference Material: April 22, 1980. United States Environmental Protection Agency, P.O. Box 93478, Las Vegas, NV 89193-3478.

${ }^{5}$ NIST Standard Reference Material: 4334E. United States Department of Commerce, National Institute of Standards and Technology, Gaithersburg, MD 20899-0001.

${ }^{6}$ NIST Standard Reference Material: 4320. United States Department of Commerce, National Institute of Standards and Technology, Gaithersburg, MD 20899-0001. 
scintillators, produced inconsistent recoveries of less than 82 percent. A new extractive scintillator containing octyl (phenyl), N,N-diisobutyl carbamoylmethylphosphine oxide (CMPO) was produced. This extractant has been characterized by Horowitz, et. al. (Horowitz 1990) and has a high distribution coefficient for curium and americium in 1 to $3 \mathrm{M} \mathrm{HNO}_{3}$. Tests of six samples, spiked with ${ }^{244} \mathrm{Cm}$ standard ${ }^{6}$, conducted with the new extractive scintillator indicated that acid concentrations greater than $0.1 \mathrm{M} \mathrm{HNO}_{3}$

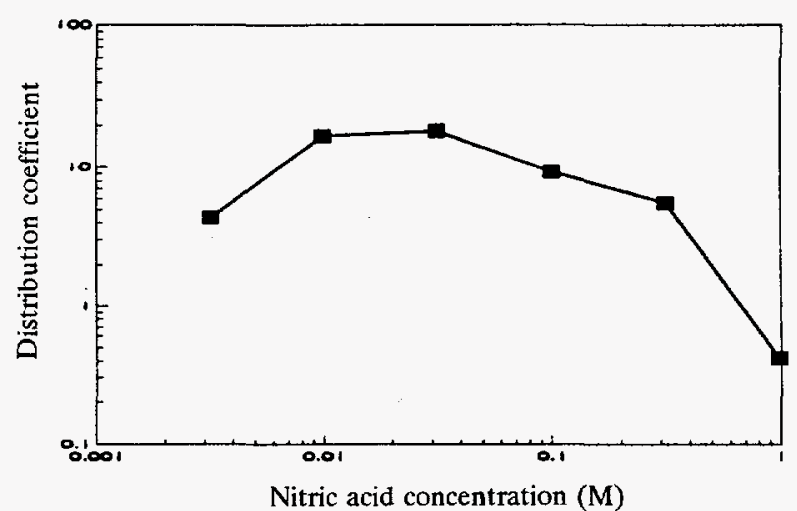

Figure 3.2. The distribution of curium from an aqueous solution $1 \mathrm{M}$ in $\mathrm{Al}\left(\mathrm{NO}_{3}\right)_{3}$ to a $\mathrm{CMPO}$ extractive scintillator as a function of nitric acid concentration. produced significant quenching of the time and energy signals in the extractive scintillator. Recoveries of 94 percent (distribution coefficient 15 - 18) were observed at $\mathrm{pH}$ values between 1.5 and 2.0 (Figure 3.2). This is still a relatively poor distribution coefficient for samples where some interferences may be present. Two extractions are necessary to ensure that 95 percent or more of the nuclide is recovered and determined. Since the organic phase from the two extractions may be combined for counting, this additional step adds little time to the overall procedure. The CMPO scintillator is not specific for curium or americium. If other actinides are known to be present, then a procedure to separate the nuclides by sequential extractions should be used.

\subsubsection{The Extraction of Plutonium, Curium, and Uranium by Sequential} Solvent Extraction. The alpha emissions from the isotopes of curium are much higher than those from uranium (Table 3.1), and they may be easily resolved on the PERALS energy spectrum. Consequently, it is reasonable to separate these nuclides together and separate their isotopes on the spectrometer. This will also reduce the probability of a lab error resulting from sample handling. A new extractive scintillator containing bis(2-ethylhexyl) hydrogen phosphate (HDEHP) and CMPO was produced for this purpose. The new mixed scintillator was tested by extracting aluminum nitrate solutions spiked with standards of curium and uranium over a range of acid concentrations (Figure 3.3). The distribution coefficients for curium were

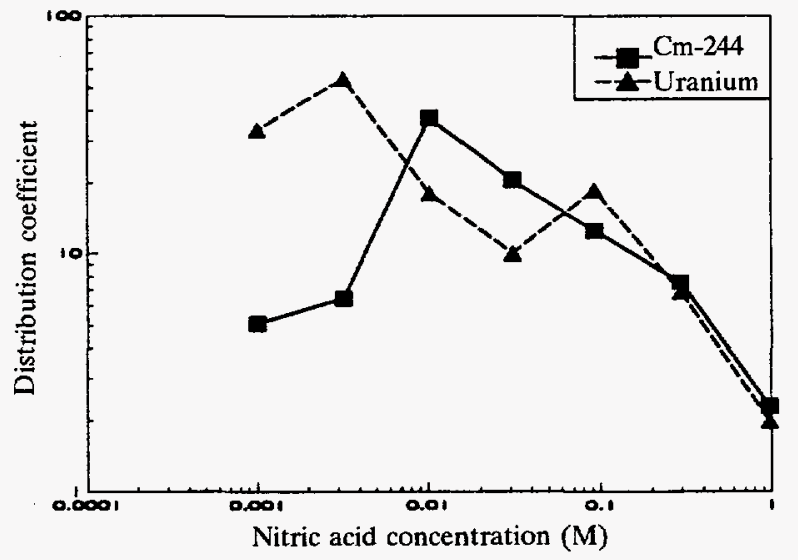

Figure 3.3. The distribution of curium and uranium from an aqueous solution $1 \mathrm{M}$ in $\mathrm{Al}\left(\mathrm{NO}_{3}\right)_{3}$ to a $\mathrm{CMPO}$ plus HDEHP extractive scintillator as a function of nitric acid concentration. 
similar to those obtained from the CMPO scintillator described above. The uranium recovery is lower than that reported in other works (McDowell 1994) where an HDEHPbased extractive scintillator was used. The aluminum co-extracts with

Table 3.1. Common Isotopes of Plutonium, Curium, and Uranium and their Alpha Emissions

\begin{tabular}{|c|c|c|c|c|c|c|c|c|}
\hline Isotope & $\begin{array}{c}\alpha \\
\text { Energy } \\
(\mathrm{MeV})\end{array}$ & Yield & Isotope & $\begin{array}{c}\alpha \text { Energy } \\
\text { (MeV) }\end{array}$ & Yield & Isotope & $\begin{array}{l}\alpha \text { Energy } \\
(\mathrm{MeV})\end{array}$ & Yield \\
\hline \multirow[t]{2}{*}{ Pu-238 } & 5.46 & $28 \%$ & \multirow[t]{2}{*}{$\mathrm{Cm}-242$} & 6.07 & $26 \%$ & \multirow[t]{2}{*}{ U-234 } & 4.77 & $72 \%$ \\
\hline & 5.50 & $72 \%$ & & 6.12 & $74 \%$ & & 4.72 & $28 \%$ \\
\hline \multirow{4}{*}{ Pu-239 } & \multirow{2}{*}{5.11} & \multirow{2}{*}{$11 \%$} & \multirow{4}{*}{$\mathrm{Cm}-243$} & 5.74 & $11.5 \%$ & \multirow{4}{*}{ U-235 } & 4.58 & $8 \%$ \\
\hline & & & & 5.79 & $73 \%$ & & 4.40 & $57 \%$ \\
\hline & \multirow[t]{2}{*}{5.16} & \multirow[t]{2}{*}{$88 \%$} & & 5.99 & $6 \%$ & & \multirow{2}{*}{4.37} & \multirow{2}{*}{$18 \%$} \\
\hline & & & & 6.06 & $6 \%$ & & & \\
\hline \multirow[t]{2}{*}{ Pu-240 } & 5.12 & $24 \%$ & \multirow[t]{2}{*}{$\mathrm{Cm}-244$} & 5.77 & $23 \%$ & \multirow[t]{2}{*}{ U-238 } & 4.20 & $75 \%$ \\
\hline & 5.17 & $76 \%$ & & 5.81 & $77 \%$ & & 4.15 & $25 \%$ \\
\hline
\end{tabular}

the uranium in this sample, thereby reducing the distribution coefficient of the uranium. If an aqueous solution $1 M$ in sodium nitrate is substituted for the aluminum nitrate, the uranium distribution coefficient increases by more than an order of magnitude. Aluminum nitrate is necessary to complex any residual fluoride ions that may be in the solution as a result of the hydrofluoric acid treatments of the original sample.

The method consists of first extracting the isotopes of plutonium in a manner similar to the plutonium procedure described above. The aqueous phase from the original extraction and the three nitric washes are combined, and the isotopes of curium and uranium are extracted from this solution with the mixed scintillator. Two extractions with the mixed scintillator are necessary to ensure that the recovery of the curium isotopes is greater than 95 percent.

\section{Intercomparison of Test Methods.}

Arthur Eidson, et. al. (Eidson 1980) obtained yellowcake samples from two uranium mills and subjected them to infrared analysis, in vitro testing in serum ultrafiltrate (Gamble's Solution), and finally to in vivo tests in rats (Damon 1984). The solubility profiles for both compounds were complex, but showed good correlation between the 
in vitro and in vivo results. All of the original samples were consumed in the course of this testing. Two additional samples were collected from the same mills that had different lot and barrel identifications, and portions of these samples were provided by Ray Guilmette of the Inhalation Toxicology Research Institute (ITRI). These two samples were placed in large glass centrifuge tubes which were agitated to produce an airborne dispersion of the $\mathrm{U}_{3} \mathrm{O}_{8}$ powders. Two breathing zone air samples were taken in this atmosphere for each yellowcake powder. The total activity on the air filters was approximately 40 to $80 \mathrm{pCi}$. The solubility profiles for these samples were determined using the method described in Section 3 above and these results are presented in Table 4.1 and Figure 4.1 below. The samples were also evaluated by Dr. Guilmette (Guilmette 1995) using several solubility test methods and a variety of lung simulant solutions. The best match between Dr. Guilmette's experiments and the test methods of Eidson and our system is the static experiment with the sample held in a polycarbonate filter sandwich and soaked in serum lung ultrafiltrate (Gamble's solution). Both Eidson's and our method use Gamble's solution for the solvent and both use a filter sandwich to hold the sample. The preliminary results of this experiment have therefore been used for this intercomparison of the data.

4.1 Solubility Class and Dosimetry Intercomparisons. The solubility profiles for each of the experiments was fitted to a three element exponential model using a common Marquardt fitting algorithm (Kuester 1973). The fraction in each stability class was then determined from the fitted data and is presented in Table 4.1 below. These solubility profiles were then used to generate dosimetry estimates for an acute inhalation exposure of $1 \mathrm{nCi}$ of ${ }^{238} \mathrm{U}$ and $1 \mathrm{nCi}$ of ${ }^{234} \mathrm{U}(1 \mu$ Activity Median Aerodynamic Diameter (AMAD) assumed) using the Code for Internal Dosimetry - Cindy (Strenge 1990). A dosimetry estimate for an equivalent exposure using the 10 CFR Part 20 assumption of 100 percent Class $Y$ is also provided for comparison.

All methods clearly show the Mill A $\mathrm{U}_{3} \mathrm{O}_{8}$ (K1531-35-40-B in Guilmette 1995) to be far more soluble than the Mill D compound (E-200-C); however, there are obvious differences between the lots of yellowcake examined by Eidson and Damon and the ones analyzed by Guilmette and reported in this work. The solubility profile for the later Mill A $\mathrm{U}_{3} \mathrm{O}_{8}$ indicated that this compound was quite soluble, with 99 percent falling into Class D while the earlier samples had a larger fraction of Class $Y$ compound. Mill D was more insoluble in all tests, although the fraction in Class $Y$ varied among the test methods with the later

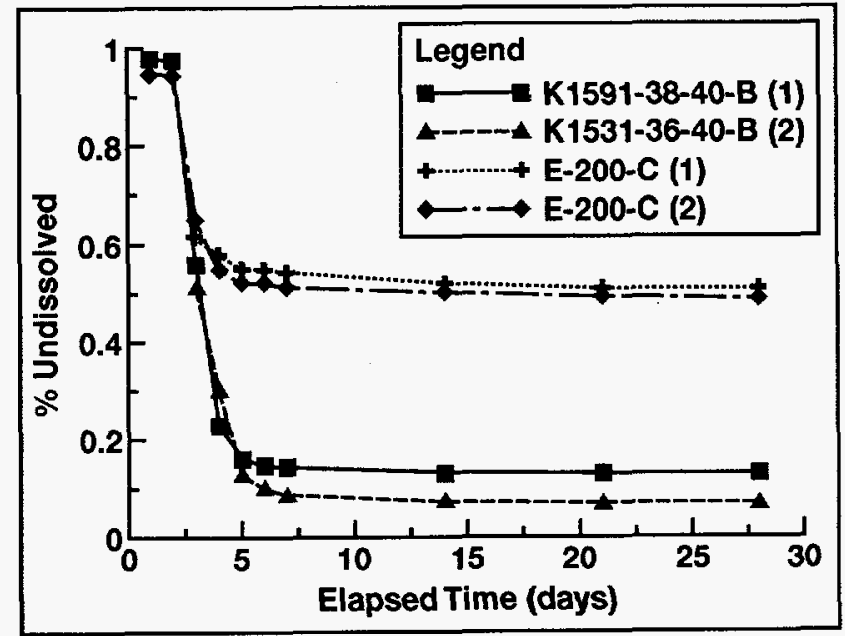

Figure 4.1 Solubility profiles of ITRI $\mathrm{U}_{3} \mathrm{O}_{8}$ samples from same mill as those analyzed by Eidson and Damon. 
sample again being more soluble than the ones used by Eidson and Damon.

The 50 year Effective Dose Equivalent estimate ranged from 5.8 to 48 mrem for the different Mill A tests, and from 13 to $190 \mathrm{mrem}$ for the more insoluble Mill D compound. The dose estimates are strongly influenced by the fraction assigned to Class $Y$, as the insoluble fraction produces the highest effective dose equivalent. The 100 percent Class $Y$ assumption produced a dose estimate of 250 mrem (Table 4.2).

Table 4.1. Intercomparison of Solubility Tests on $\mathrm{U}_{3} \mathrm{O}_{8}$ Samples

\begin{tabular}{||l|c|c|c||c|c|c||}
\hline & \multicolumn{2}{|c|}{ Mill A - U(K) Solubility Class } & \multicolumn{2}{c|}{ Mill D - U(E) Solubility Class } \\
\cline { 2 - 7 } & $\mathrm{D}$ & $\mathrm{W}$ & $\mathrm{Y}$ & $\mathrm{D}$ & $\mathrm{W}$ & $\mathrm{Y}$ \\
\hline Eidson, 1980 (In Vitro) & 0.86 & 0 & 0.15 & 0.26 & 0 & 0.75 \\
\hline Damon, 1984 (In Vivo) & 0.85 & 0 & 0.15 & 0.25 & 0 & 0.75 \\
\hline Metzger, 1994 (In Vitro)* & 0.99 & 0 & 0.01 & 0.52 & 0 & 0.48 \\
\hline $\begin{array}{l}\text { Guilmette, 1995 (In } \\
\text { Vitro) }\end{array}$ & 1.0 & 0 & 0 & 0.24 & 0.76 & 0 \\
\hline
\end{tabular}

" $\mathrm{U}_{3} \mathrm{O}_{3}$ had different Batch and Lot No. from that used by Eidson \& Damon. tPolycarbonate Filter, SUF, at $20^{\circ} \mathrm{C}$.

Table 4. 2. Intercomparison of Estimated Doses from an Acute Inhalation Dose of $2 \mathrm{nCi}$ of the $\mathrm{U}_{3} \mathrm{O}_{8}$ Compounds Described in Table 4.1 Above. $(A M A D=1 \mu)$.

\begin{tabular}{||l|c|c||}
\hline \multirow{2}{*}{} & \multicolumn{2}{|c|}{ 50 Year Effective Dose Equivalent (mrem) } \\
\cline { 2 - 3 } & Mill A - U(K) & Mill D - U(E) \\
\cline { 2 - 3 } & Cindy & Cindy \\
\hline Eidson, 1980 & 43 & 190 \\
\hline Damon, 1984 & 43 & 190 \\
\hline Metzger, 1994 & 8.3 & 120 \\
\hline Guilmette, 1995 & 5.8 & 13 \\
\hline 10 CFR20 - 100\% Y & 250 & 250 \\
\hline
\end{tabular}

\section{Inorganic Lung Simulant Solutions.}


Henge-Napoli (Henge-Napoli 1989) suggested that simple solutions of $0.03 \mathrm{M} \mathrm{NaHCO}_{3}$ or $0.001 \mathrm{M} \mathrm{NaH}_{2} \mathrm{PO} 4$ would produce reasonable solubility profiles for many compounds. These simple lung simulants, if they produce reasonable results, would simplify the test methods described earlier. The Gamble's solution requires several days to synthesize in large volumes due to the relative insolubility of some of the organic components, and the sample preparation necessary to destroy these organic constituents prior to extraction of the nuclides of interest requires several hours. A robust lung simulant without organic components would speed and simplify the methods described in previous sections.

Since yellowcake is a major compound of concern with frequently complex solubility profiles ranging from soluble to insoluble, a sample of $\mathrm{U}_{3} \mathrm{O}_{8}$ dried at low temperature was chosen to test each of the simple lung simulants against Gamble's solution. The yellowcake sample was taken from a local uranium mill for this test as the quantity of the samples provided by ITRI was not sufficient to stage this experiment. The $\mathrm{U}_{3} \mathrm{O}_{8}$ from this mill was dried in a propane furnace at a relatively low temperature, so the resulting yellowcake would be expected to be mostly soluble.

5.1.1. Extraction of Uranium from the Simple Lung Fluid Simulants. Liter samples of the carbonate and phosphate solutions were spiked with natural uranium solution standards. The solutions were acidified to a $\mathrm{pH}$ of $2-3$ with $4 \mathrm{~N} \mathrm{HNO}_{3}$ and were extracted directly with ALPHAEX in $90-\mathrm{mL}$ aliquots and were counted on the PERALS spectrometer. Recovery of the uranium from each sample exceeded 97 percent. No further sample processing is necessary for these simple simulants.

At the time this experiment was performed, the air filters were being directly counted on the PERALS spectrometer after being immersed in a scintillation cocktail. This method of counting the insoluble fraction of the dust in the filter produced a $99+$ percent counting efficiency but a degraded energy spectra and was subsequently abandoned in favor of the filter dissolution method described in Section 3 above.

5.1.2. The Solubility Test. The yellowcake powder was placed in a long centrifuge tube and was agitated to create an airborne dispersion of the dust. Air samples were taken from this dispersion with a breathing zone air pump until approximately $70 \mathrm{pCi}$ of uranium was on the filters. Each filter was covered with a clean filter of the same type to make a sandwich and was placed in a holder consisting of the center sections of two standard three part breathing zone filter cassettes. Each filter was then submersed in $90 \mathrm{~mL}$ of the Gamble's solution, or $90 \mathrm{~mL}$ of the phosphate or carbonate solutions described above. The filter sandwiches were moved to new beakers every four hours for the first day, every day until the end of the first week, and then weekly until the end of the 28 day test period. The Gamble's solution was treated according to the method described in Section 3 above, and the simple lung simulants were simply $\mathrm{pH}$ adjusted with nitric acid before extraction of the uranium. After the completion of the leach testing, the filter media and the undissolved $\mathrm{U}_{3} \mathrm{O}_{8}$ were dried and immersed in ALPHAEX and counted directly on the PERALS spectrometer. 
Results of the simple simulant tests are shown in Table 5.1 and Figure 5.1 below. The solubility profile of the Gamble's solution was consistent with other reports for yellowcake dried at low temperatures (Alexander 1986). Neither of the simple simulant solutions produced profiles that were similar to the Gamble's solution. The carbonate solution put most of the $\mathrm{U}_{3} \mathrm{O}_{8}$ into solution within the first four hours of the test, while the phosphate solution produced an insoluble mass that remained in the filter sandwich.

Table 5.1. Simple Lung Fluid Solvent Test on a $\mathrm{U}_{3} \mathrm{O}_{8}$ Sample

\begin{tabular}{||c|c|c|c|}
\hline \multirow{2}{*}{$\begin{array}{l}\text { Lung Simulant } \\
\text { Solution }\end{array}$} & \multicolumn{3}{|c|}{ Solubility Class } \\
\cline { 2 - 4 } & $\mathrm{D}$ & W & $\mathrm{Y}$ \\
\hline Gamble's & 0.78 & 0.22 & 0 \\
\hline $0.03 \mathrm{M} \mathrm{NaHCO}_{3}$ & 0.99 & 0.01 & 0 \\
\hline $0.001 \mathrm{M} \mathrm{NaH}_{2} \mathrm{PO}_{4}$ & 0.03 & 0.02 & 95 \\
\hline
\end{tabular}

In the other published work with these simple simulants (Henge-Napoli 1989), these solutions were found to adequately model the dissolution rate of $\mathrm{U}_{3} \mathrm{O}_{8}$ in Gamble's solution and in rodents. A highly insoluble form of yellowcake ( $95 \%$ Class $\mathrm{Y}$ ) was used in this study. For compounds that are highly soluble or insoluble, many simple lung simulants may give reasonable answers that will not be seen for compounds with complex profiles. In his more recent tests, Guilmette (Guilmette 1995) has found that different solvent solutions can produce wideiy varying solubility profiles for the same sample of $\mathrm{U}_{3} \mathrm{O}_{8}$.

As described in Section 1, the chemical and physical environment in the lung is complex. The phosphates and hydroxide ions in lung fluids act as precipitating agents for multivalent metal ions such as uranium. The organic acids, amino acids and proteins act as natural chelating agents (Kanapilly 1977). It is apparent that the organic components of the extracellular lung fluid and the microenvironment of the phagolysosome play a significant role in the dissolution and clearance of dusts from the lungs. It is unlikely that a simple lung simulant solution without organic components can be found that is

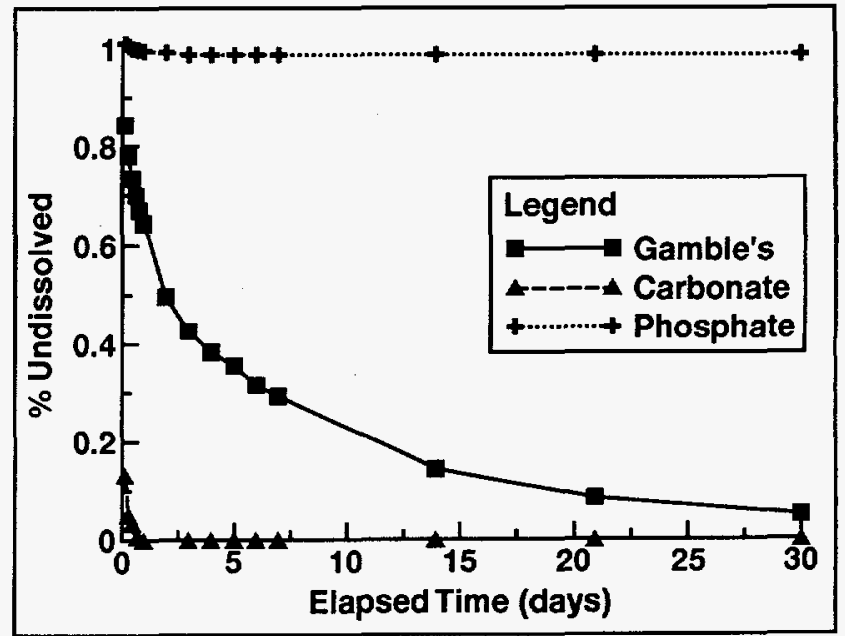

Figure 5.1 Solubility of a $\mathrm{U}_{3} \mathrm{O}_{8}$ sample using Gamble's solution and simple lung stimulants. 
sufficiently robust to determine solubility profiles in the human lung for unknown compounds found in the workplace.

\section{Conclusion}

Recent changes in regulations (10 CFR 20.1204) allow licensees to use the physical and chemical properties of the airborne radioactive isotopes found in their workplace to alter the Derived Air Concentration (DAC) and the Annual Limit of Intake (ALI) limits based on the solubility of the airborne compounds. In addition to chemical solubility, particle size and other physical factors play a significant role in the deposition and the clearance of the radioactive compounds from the human lung. Solubility tests performed on bulk product samples may not accurately represent the particle size distribution or the chemical composition of aerosols found in different work areas of a plant or facility. The chemical composition of a nuclide, such as uranium, commonly changes as it is processed from ore to final dried product, and airborne concentrations often contain a mixture of compounds. Solubility tests performed on air samples conducted in the work areas of a plant offer the best representation of the probable lung uptake and retention of the radionuclides of interest.

While in vitro solubility testing has been conducted in a research setting for more than two decades, no "standard method" has evolved for use in industrial and medical settings. Most methods are expensive, technically complex, and lack the sensitivity to determine solubility profiles from workplace air samples. Considering the complexity of dust deposition, dissolution and clearance of particles from the human lung, no single in vitro test method will adequately model all airborne radioactive compounds. Nonetheless, the paucity of test data on many compounds has left facility operators and regulators alike assigning solubility data based on theoretical estimates of solubility that are sometimes little better than an outright guess. The test methods developed in this work allows in vitro solubility profiles for most common actinides to be determined from breathing zone and area air samples. Straightforward solvent extraction chemistry techniques allow the nuclides of interest to be phase transferred to an extractive scintillator, frequently in a single step. This reduces the time, and ultimately the cost of performing the test, thereby making solubility testing more accessible to licensees. As in any in vitro test, correlation of the solubility profiles with human bioassay or in vivo whole body counting data is crucial to validating the accuracy of the method. Whenever possible, the results of solubility tests should be carefully compared to available bioassay data before changes in solubility classes are made.

\section{References:}

Abuzeida, M., Arebi, B.H., Zolatarev, Y.A., Komarov, N.A., "Selective Liquid Scintillation 
Method of Uranium $\alpha$-Spectrometry," Journal of Radioanalytical and Nuclear Chemistry, Articles Vol. 116, No. 2:285-289, 1987.

Alexander, R. E., Neel, R. B., Puskin, J. S., Brodsky, A., Internal Dosimetry Model for Applications to Bioassay at Uranium Mills, U.S. Nuclear Regulatory Commission, NUREG-0874, 1986

Cadieux, J. R., "Evaluation of a Photon/Electron-Rejecting Alpha Liquid Scintillation (PERALS) Spectrometer for the Measurement of Alpha-Emitting Radionuclides," Nuclear Instruments and Methods in Physics Research, A299:119-122, 1990.

Code of Federal Regulations, Title 10, Part 20, "Standards for Protection Against Radiation," U.S. Government Printing Office, Energy, 1995.

Cooke, N. and Holt, F.B., "The Solubility of Some Uranium Compounds in Simulated Lung Fluid," Health Physics, 27:69-77, 1974.

Damon, E.G., Eidson, A.F., Hahn, F.F., Griffith Jr., W.C., Guilmette, R.A., "Comparison of Early Lung Clearance of Yellowcake Aerosols in Rats with In Vitro Dissolution and IR Analysis," Health Physics, 46:859-866, 1984.

Dennis, N.A., Blear, H.M., Kent, J.E., "Dissolution Fractions and Half-times of Single Source Yellowcake in Simulated Lung Fluids," Health Physics, 42:469-477, 1982.

Eidson, A.F., "Comparison of Physical Chemical Properties of Powders and Respirable Aerosols of Industrial Mixed Uranium and Plutonium Oxide Fuels," Health Physics, 42:531-536, 1982.

Eidson, A. F., Damon, E.G., "Predicted Deposition Rates of Uranium Yellowcake Aerosols Sampled in Uranium Mills," Health Physics, 46:165-176, 1984.

Eidson, A.F., Damon, E.G., Hahn, F.F., Griffith Jr., W.C., "The Utility of In Vitro Solubility Testing in Assessment of Uranium Exposure," Radiation Protection Dosimetry, 26:64-74, 1989.

Eidson, A.F., Griffith Jr., W.C., "Techniques for Yellowcake Dissolution Studies In Vitro and their Use in Bioassay Interpretation," Health Physics, 46:151-163, 1984.

Eidson, A.F., Griffith Jr., W.C., Hahn, F.F., Pickrell, J.A., "A Model for Scaling the Results of U Excretion Rate Studies in Beagle Dogs to Man," Health Physics, 57:199-210, 1989.

Eidson, A.F., Mewhinney, J.A., "In Vitro Dissolution of Respirable Aerosols of Industrial Uranium and Plutonium Mixed-Oxide Nuclear Fuels," Health Physics, 45:1023-1037, 
1983.

Eidson, A.F., Mewhinney, J.A., "In Vitro Solubility of Yellowcake Samples from Four Uranium Mills and the Implications for Bioassay Interpretation," Health Physics, 39:893-902, 1980.

Guilmette, R.A., "Preliminary Draft Report for Nuclear Regulatory Commission Project: Solubility Measurements for Implementing 10 CFR Part 20," Inhalation Toxicology Research Institute, 1995.

Guilmette, R.A., Kanapilly, G.M., Lundgren, D.L., Eidson A.F., "Biokinetics of Inhaled $244 \mathrm{Cm}$ Oxide in the Rat: Effect of Heat Treatment at 1150 degrees C, Health Physics, 46:845-858, 1984.

Henge-Napoli, M.H., Rongier, E., Ansoborlo, E., Chalabreysse, J., "Comparison of the In Vitro and In Vivo Dissolution Rates of Two Diuranates and Research on an Early Urinary Indicator of Renal Failure in Humans and Animals Poisoned with Uranium," Radiation Protection Dosimetry, 26:113-117, 1989.

Horowitz, E.P., Dietz, M.L., Nelson, D.M., LaRosa, J.J., Fairman, W.D., "Concentration and Separation of Actinides from Urine Using a Support Bifunctional Organophosphorus Extractant," Analytica Chimica Acta., 238:263-271, 1990.

ICRP Publication 30, Parts 1,2 \& 4, "Limits for Intakes of Radionuclides by Workers," Annals of the ICRP, Pergamon Press, Oxford, 1979.

Kanapilly, G.M., "Alveolar Microenvironment and Its Relationship to the Retention and Transport Into Blood of Aerosols Deposited in the Alveoli," Health Physics, 32:89100, 1977.

Kuester, J.L. and Mize, J.H., Optimization Techniques with Fortran, McGraw-Hill, New York, 1973.

Lieberman, R., "Eastern Environmental Radiation Facility Radiochemistry Procedures Manual", US Environmental Protection Agency, EPA 520/5-84-006, 1984.

McDowell, W.J., "Photon/electron Rejecting Alpha Liquid Scintillation (PERALS) Spectrometry: A Review," Radioactivity and Radiochemistry, 3(2):26-54, 1992.

McDowell, W.J., Case, G.N., "A Procedure for the Determination of Uranium on Cellulose Air-Sampling Filters by Photon-Electron Rejecting Alpha Liquid Scintillation Spectrometry," ORNL/TM-10175, August 1986.

McDowell, W.J. and Case, G.N., "Separation of Radium and its Determination by 
Photon/Electron-Rejecting Alpha Liquid Scintillation (PERALS) Spectrometry," Radioactivity \& Radiochemistry, 1(4):58-69, Fall 1990.

McDowell, W.J. and McDowell, B.L., Liquid Scintillation Alpha Spectrometry, CRC Press, Inc., Boca Raton, FL, 1994.

McDowell, W.J., Farrar, D.T., and Billings, M.R, "Plutonium and Uranium Determinations in Environmental Samples; Combined Solvent Extraction-Liquid Scintillation Method," Talanta, 21:1231-1245, 1974.

Metzger, R. L., McKlveen, J.W., "Specific Activity of Uranium and Thorium in Marketable Rock Phosphate as a Function of Particle Size," Health Physics ,39:69-75, 1980.

Mewhinney, J.A., Eidson, A.F., Wong, V.A., "Effect of Wet and Dry Cycles of Dissolution of Relatively Insoluble Particles Containing Pu," Health Physics, 53:377-384, 1987.

Miglio, J.J., Muggenburg, B.A., Brooks, A.L., "A Rapid Method for Determining the Relative Solubility of Plutonium Aerosols," Health Physics, 33:449-457, 1977.

Moss, O.R., "Simulants of Lung Interstitial Fluid," Health Physics, 36:447-448, 1979.

Ryan, M.T., Case, G.N., McDowell, W.J., Herly, L.C., "A Preliminary Comparison of Two Techniques for Bioassay of Urine for Plutonium," ORNL/TM-8531, December 1982.

Ryan, M.T., McDowell, W.J. Case, G.N., "Observations of the Distribution and the Nature of Alpha-Active Particulate Material in a HEPA Filter Used for PlutoniumContaining Dust," ORNL/TM-5765, 1977.

Strenge, D.L., Peloquin, R.A., Sula, M.J., Johnson, J.R., "Code for Internal Dosimetry (CINDY)," Pacific Nothwest Laboratory, Parts 1 \& 2, October 1990.

Thein M., Maitz, A.H., Austin, M.A., Rao, G.R., Gur, D., "Dissolution Rates of Airborne Uranium in Simulated Lung Fluid," Health Physics, 43:587-590, 1982. 
Appendix

Methods 


\section{Solubility Test for Uranium}

Introduction: A filter sandwich is submersed in gamble's solution, and changed daily for one week. The sandwiches are then changed once weekly for the next three weeks. The samples are analyzed after each change for the percentage of dissolved uranium.

\section{Reagents:}

Carbon dioxide, gaseous $\mathrm{CO}_{2}$.

De-ionized water (DI $\mathrm{H}_{2} \mathrm{O}$ ), $17.0 \mathrm{MOhms.}$

Gamble's solution:

\begin{tabular}{||l|l||}
\hline Salt & $\begin{array}{l}\text { Molar } \\
\text { Concentration }\end{array}$ \\
\hline $\mathrm{NaCl}$ & 0.116 \\
\hline $\mathrm{NH}_{4} \mathrm{Cl}$ & 0.010 \\
\hline $\mathrm{NaHCO}$ & 0.027 \\
\hline Glycine & 0.005 \\
\hline $\mathrm{Na}_{3}$ Citrate & 0.0002 \\
\hline $\mathrm{CaCl}_{2}$ & 0.0002 \\
\hline $\mathrm{L}-\mathrm{Cystine}_{2}$ & 0.001 \\
\hline $\mathrm{H}_{2} \mathrm{SO}_{4}$ & 0.0005 \\
\hline $\mathrm{NaH}_{2} \mathrm{PO}_{4}$ & 0.0012 \\
\hline $\mathrm{DTPA}^{\mathrm{a}}$ & 0.0002 \\
\hline $\mathrm{ABAC}^{\mathrm{b}}$ & $50 \mathrm{ppm}$ \\
\hline
\end{tabular}

'Diethylenetriaminepentaacetic acid, not present in blood serum.

bAlkylbenzyldimethylammonium chloride added as an antibacterial agent.

1. Weigh $0.961 \mathrm{~g} \mathrm{L-Cystine} \mathrm{and} \mathrm{grind} \mathrm{it} \mathrm{into} \mathrm{a} \mathrm{fine} \mathrm{powder} \mathrm{with} \mathrm{a} \mathrm{mortar}$ and pestle. [This allows for easier dissolution.]

2. Add the ground L-Cystine to $3 \mathrm{~L}$ of $\mathrm{DI} \mathrm{H}_{2} \mathrm{O}$. Begin stirring to dissolve.

3. To the same $3 \mathrm{~L}$ of $\mathrm{DI} \mathrm{H}_{2} \mathrm{O}$ as in Step 2, add the following:

$2.14 \mathrm{~g} \mathrm{NH}_{4} \mathrm{Cl}, 1.50 \mathrm{~g}$ Glycine, $0.235 \mathrm{~g} \mathrm{Na}_{3}$ Citrate, $1.18 \mathrm{~g} \mathrm{CaCl}_{2}$,

0.315 g DTPA, 8 drops ABAC, $111.6 \mu \mathrm{L}$ concentrated $\mathrm{H}_{2} \mathrm{SO}_{4}$. 
4. Dilute the solution to $4 \mathrm{~L}$ with $\mathrm{DI} \mathrm{H}_{2} \mathrm{O}$. Continue stirring over night with very low heat.

5. The next day, slowly add $0.662 \mathrm{~g} \mathrm{NaH}_{2} \mathrm{PO}, 9.07 \mathrm{~g} \mathrm{NaHCO}_{3}$, and $27.1 \mathrm{~g}$ $\mathrm{NaCl}$.

6. Re-adjust the volume of the solution to $4 \mathrm{~L}$ with $\mathrm{DI} \mathrm{H}_{2} \mathrm{O}$. Continue stirring for two days on low heat, adjusting the volume of the solution as needed.

7. Filter the Gamble's solution before usage.

Procedure:

1. After the Gamble's solution is prepared, store it under $\mathrm{CO}_{2(\mathrm{~g})}$, to maintain a $\mathrm{pH}$ of 7.2.

2. Prepare a filter sandwich by covering the air sample with a second clean filter, so that the sample is in a filter-sample-filter sandwich. The sandwich is then held together with two middle sections of standard three part breathing zone filter cassettes.

3. Place the sandwich in a beaker containing $90 \mathrm{~mL}$ of Gamble's solution.

4. Transfer the sandwich to a new beaker with $90 \mathrm{~mL}$ of Gamble's solution every day for the first week.

5. After the first week, transfer the sandwich to a new beaker with $90 \mathrm{~mL}$ of Gamble's solution once a week until the end of the 28-day test period.

6. After the sandwich has been transferred to a new beaker, analyze the Gamble's solution from the previous beaker for its uranium activity according to the desired procedure.

Data Analysis:

Determine the total sample activity and the percent undissolved for each sample (see attached data sheet). Fit the data to the three element exponential model shown below using a Marquardt or other appropriate fitting algorithm.

Percent Undissolved $=A_{1}{ }^{*} e^{-A_{2 t}}+A_{3}{ }^{*} e^{-A 4 t}+A_{5}{ }^{*} e^{-A G t}$.

Use the fitted equation to determine the fraction in each solubility class. 
Class $\mathrm{D}=$ fraction with half-time $<10$ days.

Class $W=$ fraction with half-time between 10 and 100 days.

Class $Y=$ fraction with half-time $>100$ days. 


\section{Sample Preparation for Chemistry to Extract Uranium, Plutonium, and Curium from Gamble's Solution}

Introduction: Gamble's solution is an artificial serum lung ultrafiltrate used in solubility testing of radionuclides. The Gamble's solution is wet ashed with several additions of concentrated nitric acid and hydrogen peroxide prior to separation of the radionuclides by solvent extraction. All organic components in the Gamble's solution must be destroyed, as they inhibit the phase transfer of the radionuclides to the organic extractive scintillator.

\section{Reagents:}

Nitric acid, reagent grade $\mathrm{HNO}_{3}$, concentrated.

Hydrogen peroxide, reagent grade $\mathrm{H}_{2} \mathrm{O}_{2}, 30 \%$.

De-ionized water (DI-water), $17.0 \mathrm{MOhms.}$

Gamble's solution:

\begin{tabular}{||l|l||}
\hline Salt & $\begin{array}{l}\text { Molar } \\
\text { Concentration }\end{array}$ \\
\hline $\mathrm{NaCl}$ & 0.116 \\
\hline $\mathrm{NH}_{4} \mathrm{Cl}$ & 0.010 \\
\hline $\mathrm{NaHCO}_{3}$ & 0.027 \\
\hline Glycine & 0.005 \\
\hline $\mathrm{Na}_{3}$ Citrate & 0.0002 \\
\hline $\mathrm{CaCl}_{2}$ & 0.0002 \\
\hline $\mathrm{L}_{-} \mathrm{Cystine}_{2}$ & 0.001 \\
\hline $\mathrm{H}_{2} \mathrm{SO}_{4}$ & 0.0005 \\
\hline $\mathrm{NaH}_{2} \mathrm{PO}_{4}$ & 0.0012 \\
\hline $\mathrm{DTPA}^{\mathrm{a}}$ & 0.0002 \\
\hline $\mathrm{ABAC}^{\mathrm{b}}$ & $50 \mathrm{ppm}$ \\
\hline
\end{tabular}

'Diethylenetriaminepentaacetic acid, not present in blood serum.

bAlkylbenzyldimethylammonium chloride added as an antibacterial agent.

\section{Procedure:}

1. Acidify a $90-\mathrm{mL}$ volume of the Gamble's solution with $10 \mathrm{~mL}$ of conc. $\mathrm{HNO}_{3}$. Slowly evaporate to $5 \mathrm{~mL}$ on a hot plate. 
2. Slowly add $10 \mathrm{~mL}$ of conc. $\mathrm{HNO}_{3}$ down sides of beaker. Evaporate to $4 \mathrm{~mL}$. Dense, brown, organic fumes may be observed as the organic matter boils off.

3. Repeat Step 2 until the solution is clear (two additions are normal).

4. After the third addition, set aside to cool, and add $5 \mathrm{~mL}$ of $\mathrm{H}_{2} \mathrm{O}_{2}$. Allow to stand for $\sim 5$ minutes and add an additional $5 \mathrm{~mL}$ of $\mathrm{H}_{2} \mathrm{O}_{2}$.

5. Gradually warm the solution, taking care not to allow the solution to effervesce. Evaporate until $<2 \mathrm{~mL}$ of solution remains. A precipitate of salts should form at the bottom of the beaker.

6. Proceed with the procedure for rapid extraction of the desired radionuclides from Gamble's solution. 


\section{Sample Preparation to Wet Ash Gelman GN4 ${ }^{1}$ Filters}

Introduction: Air samples taken on Gelman GN4 filter media are wet ashed with concentrated nitric acid and hydrogen peroxide prior to separation of the radionuclides by solvent extraction. Hydrofluoric acid is used to solubilize oxides of plutonium if they are suspected to be present on the filter.

\section{Reagents:}

Nitric acid, reagent grade $\mathrm{HNO}_{3}$, concentrated.

Hydrogen peroxide, reagent grade $\mathrm{H}_{2} \mathrm{O}_{2}, 30 \%$.

Hydrofluoric acid, reagent grade $\mathrm{HF}, 48 \%$.

De-ionized water (DI-water), 17.0 MOhms.

Beaker, Teflon, $100-200 \mathrm{~mL}$.

\section{Procedure:}

1. Place the filter in the bottom of the Teflon beaker and dissolve it in $10 \mathrm{~mL}$ of conc. $\mathrm{HNO}_{3}$. It may be necessary to heat slightly to dissolve.

2. Slowly add $10 \mathrm{~mL}$ of conc. $\mathrm{HNO}_{3}$ down the sides of beaker. Also add $2-3 \mathrm{~mL}$ of $\mathrm{HF}$ if necessary (see Introduction). Evaporate to $4 \mathrm{~mL}$ in a fume hood. Dense brown fumes should be observed as the organic components boil off.

3. Add $10 \mathrm{~mL}$ of conc. $\mathrm{HNO}_{3}$ and set aside to cool. Add $5 \mathrm{~mL}$ of $\mathrm{H}_{2} \mathrm{O}_{2}$. Allow to stand for $\sim 5$ minutes and add an additional $5 \mathrm{~mL}$ of $\mathrm{H}_{2} \mathrm{O}_{2}$. Wash down the sidewalls of the Teflon beaker using a plastic transfer pipet.

4. Gradually warm the solution, taking care not to allow the solution to effervesce. Evaporate until $<2 \mathrm{~mL}$ solution remains. If dense, brown, organic fumes are observed at this stage, remove from heat and repeat Steps 3 and 4. All of the HF should be fumed off at this point.

5. Proceed with the procedure for rapid extraction of the desired radionuclides from the Gelman GN4 filter solution.

${ }^{1}$ Gelman Sciences, Inc., 600 S. Wagner Rd., Ann Arbor, Michigan 48106 


\section{Extraction of Uranium from Gamble's Solution or Gelman GN4 Filter ${ }^{2}$ Media}

Introduction: After the sample has been wet ashed (see sample preparation procedure), the sample is increased to approximately $30 \mathrm{~mL}$, the $\mathrm{pH}$ is adjusted to $2-3$, and the uranium is extracted with ALPHAEX ${ }^{3}$. Finally, the sample is counted on the PERALS spectrometer. The ALPHAEX is not specific for uranium. If other alpha emitting transuranic nuclides are known to be present in the sample, an alternate procedure should be used. Recovery may be determined by spiking each sample with a ${ }^{232} \mathrm{U}$ tracer solution, if desired.

\section{Reagents:}

ALPHAEX extractive scintillator, $0.2 \mathrm{M}$ in bis(2-ethylhexyl) hydrogen phosphate (HDEHP).

Ascorbic acid, reagent grade, solid.

De-ionized water, $\left(\mathrm{DI} \mathrm{H}_{2} \mathrm{O}\right), 17.0 \mathrm{MOhms}$.

NIST-traceable ${ }^{232} \mathrm{U}$ tracer, $0.37 \mathrm{~Bq} / \mathrm{mL}(10 \mathrm{pCi} / \mathrm{mL})$.

Nitric acid, reagent grade $\mathrm{HNO}_{3}$, concentrated.

Nitric acid solution, $6 \mathrm{~N}$.

Sodium hydroxide pellets, reagent grade $\mathrm{NaOH}$.

Sodium hydroxide solution, $6 \mathrm{~N}$.

[Add $240 \mathrm{~g} \mathrm{NaOH}$ pellets to $500 \mathrm{~mL} \mathrm{DI} \mathrm{H}_{2} \mathrm{O}$. Stir to dissolve. Dilute to 1 L with DI $\mathrm{H}_{2} \mathrm{O}$.]

\section{Procedure:}

1. After $2-3 \mathrm{~mL}$ remain in the beaker, raise the volume to $-30 \mathrm{~mL}$ with $\mathrm{DI}_{2} \mathrm{O}$ and add $1 \mathrm{~mL}$ of the ${ }^{232} \mathrm{U}$ tracer solution, if desired.

2. Adjust the $\mathrm{pH}$ to $2-3$ with $6 \mathrm{~N} \mathrm{NaOH}$.

3. Transfer the sample to a pear-shaped, teflon separatory funnel. Wash the beaker twice with $\mathrm{DI} \mathrm{H}_{2} \mathrm{O}$. Transfer both washes to the separatory funnel also.

4. Add $200 \mathrm{mg}$ of ascorbic acid. Mix gently.

\footnotetext{
${ }^{2}$ Gelman Sciences, Inc., 600 S. Wagner Rd., Ann Arbor, MI 48106

${ }^{3}$ ETRAC, 1009 Alvin Weinberg Dr., Oak Ridge, TN 37830.

${ }^{4}$ ORDELA, Inc., 1009 Alvin Weinberg Dr., Oak Ridge, TN 37830.
} 
5. Add $1.50 \mathrm{~mL}$ ALPHAEX and agitate for 5 minutes. (A graduated, glass pipet or a calibrated, high-precision pipettor should be used when adding or removing volumes of extractive scintillators.) Allow the phases to separate.

6. Extract and transfer $1.00 \mathrm{~mL}$ of the organic phase to a $10 \times 75 \mathrm{~mm}$ test tube.

7. Sparge with toluene-saturated argon gas for 5 minutes and count for 1 hour on the PERALS spectrometer.

\section{Data Analysis:}

1. Integrate the peaks of ${ }^{234} \mathrm{U},{ }^{238} \mathrm{U}$, and the ${ }^{232} \mathrm{U}$ tracer, if used.

2. Determine the uranium recovery from the ${ }^{232} \mathrm{U}$ tracer. Recovery is normally $97-$ 99\%.

3. Calculate the original activity in $\mathrm{Bq}$ of each isotope identified using the following equation:

$$
U(B q)=\frac{(G R C N T-B K G) \times V_{O T}}{T T M E \times V_{O C} \times 60 \times R}
$$

where:

$\mathrm{U}=$ uranium concentration in $\mathrm{Bq}$ for each isotope.

GRCNT = gross count from integration of each uranium peak of interest.

$\mathrm{BKG}=$ background count in same region of interest (normally about 0 ).

$\mathrm{V}_{\mathrm{OT}}=$ total volume of extractive scintillator used, $(1.50 \mathrm{~mL})$.

$\mathrm{V}_{\propto C}=$ volume of extractive scintillator counted, (normally $1.00 \mathrm{~mL}$ ).

TIME $=$ Count time (minutes).

$60=\mathrm{dpm} / \mathrm{Bq}(\mathrm{dpm}=$ disintegrations per minute).

$R=$ fractional isotopic recovery

\section{Lower Limit of Detection:}

Normally, when counting most alpha-emitting isotopes on the PERALS ${ }^{\circledR}$ spectrometer, the background count under the alpha peak of interest is nearly 0 for most reasonable counting times. In such instances, the lower limit of detection (LLD) is calculated based on the probability that an alpha particle will be emitted but not counted. The following equation is used: 


$$
L L D=\frac{3 \times V_{\text {OT }}}{\operatorname{TIME} \times E F F \times V_{O C} \times 60 \times R}
$$

where:

LLD $=$ lower limit of detection in Bq.

TIME = count time in minutes.

$\mathrm{EFF}=$ efficiency of the counter $=0.99=99 \%$ for PERALS.

$\mathrm{V}_{\mathrm{OT}}=$ total volume of extractive scintillator used, $(1.50 \mathrm{~mL})$.

$\mathrm{V}_{\mathrm{OC}}=$ volume of extractive scintillator counted, $(1.00 \mathrm{~mL})$.

$60=\mathrm{dpm} / \mathrm{Bq}(\mathrm{dpm}=$ disintegrations per minute).

$\mathrm{R}=$ fractional isotopic recovery.

$3=-\ln (0.05), 0.05=5 \%=$ the probability of the occurrence of zero counts.

The LLD is normally below $0.0037 \mathrm{~Bq}$ for a one hour count. 


\section{Extraction of Uranium from Clear Water Samples \\ (DTPA Chelation Method)}

Introduction: A 200-mL sample is evaporated to $50 \mathrm{~mL}$. The sample is made $0.01 \mathrm{M}$ in DTPA to complex transuranic isotopes and hold them in the aqueous phase. The pH is adjusted and the uranium is extracted with ALPHAEX. Finally, the sample is counted on the PERALS ${ }^{6}$ spectrometer.

\section{Reagents:}

ALPHAEX extractive scintillator, $0.2 \mathrm{M}$ in bis(2-ethylhexyl) hydrogen phosphate (HDEHP).

Ascorbic acid, reagent grade, solid.

De-ionized water, (DI $\left.\mathrm{H}_{2} \mathrm{O}\right), 17.0 \mathrm{MOhms}$.

Diethylenetriamine pentaacetic acid, reagent grade DTPA, solid.

DTPA solution, $0.1 \mathrm{M}$.

[Add $3.93 \mathrm{~g}$ DTPA to $50 \mathrm{~mL} \mathrm{DI} \mathrm{H}_{2} \mathrm{O}$. Stir to begin dissolution. Dilute to $100 \mathrm{~mL}$ with $\mathrm{DI} \mathrm{H}_{2} \mathrm{O}$. Adjust the $\mathrm{pH}$ to $\sim 7.0$ by the dropwise addition of $6 \mathrm{~N} \mathrm{NaOH}$. Stir to complete dissolution.]

NIST-traceable ${ }^{232} \mathrm{U}$ tracer, $0.37 \mathrm{~Bq} / \mathrm{mL}(10 \mathrm{pCi} / \mathrm{mL})$.

Nitric acid, reagent grade $\mathrm{HNO}_{3}$, concentrated.

Nitric acid solution, $6 \mathrm{~N}$.

Sodium hydroxide pellets, reagent grade $\mathrm{NaOH}$.

Sodium hydroxide solution, $6 \mathrm{~N}$.

[Add $240 \mathrm{~g} \mathrm{NaOH}$ pellets to $500 \mathrm{~mL} \mathrm{DI} \mathrm{H}_{2} \mathrm{O}$. Stir to dissolve. Dilute to 1 L with DI $\mathrm{H}_{2} \mathrm{O}$.]

\section{Procedure:}

1. Acidify a 200-mL sample with 2-3 drops of $6 \mathrm{~N} \mathrm{HNO}_{3}$ and add $1 \mathrm{~mL}$ of the ${ }^{232} \mathrm{U}$ tracer solution.

2. Boil gently for 2-3 minutes to drive off radon and thoron.

3. Reduce the temperature of the hot plate to permit evaporation of the sample and evaporate until $\sim 50 \mathrm{~mL}$ remain in the beaker.

4. Add sufficient DTPA solution to make the sample $0.01 \mathrm{M}$ in DTPA ( $-5 \mathrm{~mL})$.

\footnotetext{
${ }^{5}$ ETRAC, 1009 Alvin Weinberg Dr., Oak Ridge, TN 37830.

${ }^{6}$ ORDELA, Inc., 1009 Alvin Weinberg Dr., Oak Ridge, TN 37830.
} 
5. Adjust the $\mathrm{pH}$ to $2-3$ with $6 \mathrm{~N} \mathrm{NaOH}$.

6. Transfer the sample to a pear-shaped, teflon separatory funnel. Wash the beaker twice with $\mathrm{DI} \mathrm{H}_{2} \mathrm{O}$. Transfer both washes to the separatory funnel also.

7. Add $200 \mathrm{mg}$ of ascorbic acid. Mix gently.

8. Add 1.50 mL ALPHAEX and agitate for 5 minutes. (A graduated, glass pipet or a calibrated, high-precision pipettor should be used when adding or removing volumes of extractive scintillators.) Allow the phases to separate.

9. Extract and transfer $1.00 \mathrm{~mL}$ of the organic phase to a $10 \times 75 \mathrm{~mm}$ test tube.

10. Sparge with toluene-saturated argon gas for 5 minutes and count for 1 hour on the PERALS spectrometer.

\section{Data Analysis:}

1. Integrate the peaks of ${ }^{234} \mathrm{U},{ }^{238} \mathrm{U}$, and the ${ }^{232} \mathrm{U}$ tracer.

2. Determine the uranium recovery from the ${ }^{232} U$ tracer (normally $>97 \%$ ).

3. Calculate the original activity in $\mathrm{Bq}$ of each isotope identified using the following equation:

$$
U(B q)=\frac{(G R C N T-B K G) \times V_{\text {OT }}}{\text { TIME } \times V_{\propto C} \times 60 \times R}
$$

where:

$\mathrm{U}=$ uranium concentration in $\mathrm{Bq}$ for each isotope.

GRCNT = gross count from integration of each uranium peak of interest. BKG = background count in same region of interest (normally about 0 ). $\mathrm{V}_{\mathrm{OT}}=$ total volume of extractive scintillator used, $(1.50 \mathrm{~mL})$.

$\mathrm{V}_{\mathrm{OC}}=$ volume of extractive scintillator counted, (normally $1.00 \mathrm{~mL}$ ).

TIME $=$ Count time (minutes).

$60=\mathrm{dpm} / \mathrm{Bq}$ (dpm = disintegrations per minute).

$\mathrm{R}=$ fractional isotopic recovery

\section{Lower Limit of Detection:}

Normally, when counting most alpha-emitting isotopes on the PERALS ${ }^{\circledR}$ spectrometer, the background count under the alpha peak of interest is nearly 0 for most 
reasonable counting times. In such instances, the lower limit of detection (LLD) is calculated based on the probability that an alpha particle will be emitted but not counted. The following equation is used:

$$
L L D=\frac{3 \times V_{\text {OT }}}{\operatorname{TIME} \times \mathrm{EFF} \times \mathrm{V}_{\mathrm{OC}} \times 60 \times \mathrm{R}}
$$

where:

LLD = lower limit of detection in Bq.

TIME = count time in minutes.

$\mathrm{EFF}=$ efficiency of the counter $=0.99=99 \%$ for PERALS .

$\mathrm{V}_{\mathrm{OT}}=$ total volume of extractive scintillator used, $(1.50 \mathrm{~mL})$.

$\mathrm{V}_{\triangle C}=$ volume of extractive scintillator counted, $(1.00 \mathrm{~mL})$.

$60=\mathrm{dpm} / \mathrm{Bq}(\mathrm{dpm}=$ disintegrations per minute $)$.

$\mathrm{R}=$ fractional isotopic recovery.

$3=-\ln (0.05), 0.05=5 \%=$ the probability of the occurrence of zero counts.

The LLD is normally below $0.0037 \mathrm{~Bq}$ for a one hour count. 


\section{Rapid Extraction of Uranium from Gelman GN4 ${ }^{7}$ Filters}

Introduction: Uranium is extracted from filter media dissolved in concentrated nitric acid or from Gamble's solution. The organic in the samples is destroyed by additions of concentrated nitric acid and hydrogen peroxide. Once all organics are destroyed, the solution is converted to a sulfate system, and then diluted with a solution of aluminum and sodium sulfate to complex ions that will interfere with the extraction of the uranium by the tertiary amine. Finally, the uranium isotopes are phase transferred to a tri-octyl amine based extractive scintillator (URAEX) and counted on the PERALS ${ }^{8}$ spectrometer. If polonium-210 is present in the sample, it will also be extracted, and will therefore bias the ${ }^{232} \mathrm{U}$ recovery.

\section{Reagents:}

NIST-traceable ${ }^{232} \mathrm{U}$ tracer, $0.37 \mathrm{~Bq} / \mathrm{mL}(10 \mathrm{pCi} / \mathrm{mL})$.

Uranium extractive scintillator (URAEX ${ }^{9}$ )

Nitric acid, reagent grade $\mathrm{HNO}_{3}$, concentrated.

Sulfuric acid, reagent grade $\mathrm{H}_{2} \mathrm{SO}_{4}$, concentrated.

De-ionized water (DI-water), $17.0 \mathrm{MOhms}$.

Sodium hydroxide solution, $3 \mathrm{~N} \mathrm{NaOH}$

Hydrogen peroxide, reagent grade $\mathrm{H}_{2} \mathrm{O}_{2}, 30 \%$.

Solution $0.3 \mathrm{M}$ in $\mathrm{Al}^{3+}$ and $1 \mathrm{M} \mathrm{SO}_{4}{ }^{2-}$.

[Add 16.2 $\mathrm{g}$ of $\mathrm{Al}_{2}\left(\mathrm{SO}_{4}\right)_{3}{ }^{\circ}(14-18) \mathrm{H}_{2} \mathrm{O}$ and $90.7 \mathrm{~g}$ of $\mathrm{Na}_{2} \mathrm{SO}_{4}$ to $500 \mathrm{~mL}$ of DIwater. Stir to dissolve. Dilute to $1 \mathrm{~L}$.]

Ascorbic acid, reagent grade, solid.

\section{Procedure:}

1. Add $1 \mathrm{~mL}$ of the ${ }^{232} \mathrm{U}$ tracer solution to the Gelman filter or to a sample of Gamble's solution in a Teflon beaker.

2. Dissolve the filter or destroy the organic material in the Gamble's solution according to the sample preparation procedures.

3. Add $\sim 0.5 \mathrm{~mL}$ of conc. $\mathrm{H}_{2} \mathrm{SO}_{4}$ to the solution.

4. Place the Teflon beaker on a hot plate and evaporate to essential dryness on low

${ }^{7}$ Gelman Sciences, Inc., 600 S. Wagner Rd., Ann Arbor, Michigan 48106

${ }^{8}$ ORDELA, Inc., 1009 Alvin Weinberg Dr., Oak Ridge, TN 37830

${ }^{9}$ ETRAC, 1009 Alvin Weinberg Dr., Oak Ridge, TN 37830 
heat. Raise the temperature on the hot plate to $190^{\circ} \mathrm{C}$ and heat for ten minutes. The nitric acid should fume off at $120^{\circ} \mathrm{C}$ leaving no nitrates in the beaker. Any black residue is due to organic components that were not completely destroyed during sample preparation. The sample volume must be increased with $30 \mathrm{~mL}$ DI-water and additional treatments with conc. $\mathrm{HNO}_{3}$ and $\mathrm{H}_{2} \mathrm{O}_{2}$ are necessary before proceeding.

5. Slowly add $-10 \mathrm{~mL}$ DI-water and repeat Step 4 .

6. When $<1 \mathrm{~mL}$ of solution remains, set the beaker aside to cool.

7. Add a sufficient volume of the solution of $0.3 \mathrm{M} \mathrm{Al}^{3+}$ and $1 \mathrm{M} \mathrm{SO}_{4}^{2-}$ to yield a final volume of $20-30 \mathrm{~mL}$.

8. Transfer the solution to a centrifuge tube or a separatory funnel.

9. Slowly adjust the $\mathrm{pH}$ to $\sim 0.8$ by the dropwise addition of $3 \mathrm{~N} \mathrm{NaOH}$.

10. If the air sample is thought to have Fe present, add $200 \mathrm{mg}$ of ascorbic acid to the solution to reduce the Fe just prior to Step 11.

11. Add $1.50 \mathrm{~mL}$ URAEX and agitate for 3-4 minutes. (A graduated, glass pipet or a calibrated, high-precision pipettor should be used when adding or removing volumes of extractive scintillators.)

12. Allow the phases to separate or centrifuge. Once the phases have separated, pipet $1.00 \mathrm{~mL}$ of the organic into a $10 \times 75 \mathrm{~mm}$ test tube. Sparge the scintillator with toluene-saturated argon gas for 5 minutes.

13. Count for one hour on the PERALS spectrometer.

\section{Data Analysis:}

1. Integrate the peaks of ${ }^{234} \mathrm{U},{ }^{238} \mathrm{U}$, and the ${ }^{232} \mathrm{U}$ tracer.

2. Determine the uranium recovery from the ${ }^{232} \mathrm{U}$ peak.

3. Calculate the original activity of ${ }^{234} \mathrm{U}$ and ${ }^{238} \mathrm{U}$ in $\mathrm{Bq}$ using the following equation:

$$
U(B q)=\frac{(G R C N T-B K G) \times V_{\text {OT }}}{\text { TIME } \times V_{O C} \times 60 \times R}
$$

where: 
$\mathrm{U}=$ uranium activity in $\mathrm{Bq}$ for each isotope.

GRCNT = gross count from integration of each uranium peak of interest.

$B K G=$ background count in same region of interest (normally about 0 ).

$\mathrm{V}_{\mathrm{OT}}=$ total volume of extractive scintillator used, $(1.50 \mathrm{~mL})$.

$\mathrm{V}_{O C}=$ volume of extractive scintillator counted, $(1.00 \mathrm{~mL})$.

TIME = count time (minutes).

$60=\mathrm{dpm} / \mathrm{Bq}(\mathrm{dpm}=$ disintegrations per minute) .

$R=$ fractional uranium recovery

\section{Lower Limit of Detection:}

Normally, when counting most alpha-emitting isotopes on the PERALS spectrometer, the background count under the alpha peak of interest is nearly 0 for most reasonable counting times. In such instances, the lower limit of detection (LLD) is calculated based on the probability that an alpha particle will be emitted but not counted. The following equation is used:

$$
L L D=\frac{3 \times V_{O T}}{T T M E \times E F F \times V_{O C} \times 60 \times R}
$$

where:

LLD $=$ lower limit of detection in Bq.

TIME = count time in minutes.

$\mathrm{EFF}=$ efficiency of the counter $=0.99=99 \%$ for PERALS.

$\mathrm{V}_{\mathrm{OT}}=$ total volume of extractive scintillator used $(1.50 \mathrm{~mL})$.

$\mathrm{V}_{\mathrm{OC}}=$ volume of extractive scintillator counted $(1.00 \mathrm{~mL})$.

$60=\mathrm{dpm} / \mathrm{Bq}(\mathrm{dpm}=$ disintegrations per minute) .

$\mathrm{R}=$ fractional ${ }^{232} \mathrm{U}$ recovery.

$3=-\ln (0.05), 0.05=5 \%=$ the probability of the occurrence of zero counts. 


\section{Chemistry for Rapid Extraction of Plutonium from Gelman GN4 ${ }^{10}$ Filter Media}

Introduction: Plutonium is extracted from Filter Media dissolved in concentrated nitric acid or from Gamble's Solution. The valence of plutonium is reduced to +3 or +4 by the addition of ferrous sulfate and then oxidized to +4 by the addition of sodium nitrite. The plutonium is then extracted with a $0.3 \mathrm{M}$ tertiary amine nitrate solution in toluene. The organic solution is diluted with 2-ethyl-1-hexanol, and then the plutonium is stripped from the organic phase with a $1 \mathrm{~N}$ sulfuric acid/1 $\mathrm{M}$ sodium sulfate solution. Finally, the plutonium is extracted with THOREX ${ }^{11}$ and counted on the PERALS ${ }^{12}$ spectrometer.

\section{Reagents:}

De-ionized water $\left(\mathrm{DI} \mathrm{H} \mathrm{H}_{2} \mathrm{O}\right), 17.0 \mathrm{MOhms}$.

Tri-n-octyl amine solution ( $0.3 \mathrm{M}$ amine in scintillation-grade toluene).

THOREX, extractive scintillator.

2-ethyl-1-hexanol, reagent grade; or toluene, scintillation grade.

Ferrous sulfate, $\mathrm{FeSO}_{4} \cdot 7 \mathrm{H}_{2} \mathrm{O}$, solid.

Sodium nitrite, $\mathrm{NaNO}_{2}$, solid.

Nitric acid, reagent grade $\mathrm{HNO}_{3}$, concentrated.

Nitric acid, $0.7 \mathrm{M}$ solution.

Sulfuric acid, reagent grade $\mathrm{H}_{2} \mathrm{SO}_{4}$, concentrated.

Sulfuric acid, $1 \mathrm{~N}$ solution.

Nitrate solution, $3 \mathrm{M}^{\text {in } \mathrm{NO}_{3}^{-}}$

[Add $558 \mathrm{~g} \mathrm{Al}\left(\mathrm{NO}_{3}\right)_{3} \cdot 9 \mathrm{H}_{2} \mathrm{O}$ to $500 \mathrm{~mL}\left(\mathrm{DI} \mathrm{H}_{2} \mathrm{O}\right)$. Stir to dissolve, then dilute to $1 \mathrm{~L}$ with $\mathrm{DI} \mathrm{H}_{2} \mathrm{O}$.]

Solution of sulfuric acid and sodium sulfate ( $1 \mathrm{~N}$ sulfuric acid/1 $\mathrm{M}$ sodium sulfate).

[Add $142.04 \mathrm{~g}$ of $\mathrm{Na}_{2} \mathrm{SO}_{4}$ to $500 \mathrm{~mL} 1 \mathrm{~N}$ sulfuric acid solution. Stir to dissolve, then dilute to $1 \mathrm{~L}$ with $1 \mathrm{~N} \mathrm{H}_{2} \mathrm{SO}_{4}$.]

NIST-traceable ${ }^{242} \mathrm{Pu}$ tracer, $0.37 \mathrm{~Bq} / \mathrm{mL}(10 \mathrm{pCi} / \mathrm{mL})$.

\section{Procedure:}

1. After $<2 \mathrm{~mL}$ of conc. $\mathrm{HNO}_{3}$ solution remain in the beaker, dilute the sample to 20-30 mL with DI $\mathrm{H}_{2} \mathrm{O}$ if working out of Gamble's solution. If working from filter media solution, dilute the sample to $10-20 \mathrm{~mL}$ with $3 \mathrm{M}$ nitrate solution, made

\footnotetext{
${ }^{10}$ Gelman Sciences Inc., 600 South Wagner Rd., Ann Arbor, Michigan 48106

${ }^{11}$ ETRAC, 1009 Alvin Weinberg Dr., Oak Ridge, TN 37830

${ }^{12}$ ORDELA, Inc., 1009 Alvin Weinberg Dr., Oak Ridge, TN 37830
} 
from $\mathrm{Al}\left(\mathrm{NO}_{3}\right)_{3}$, to make the final solution 3-4 $\mathrm{M}$ in nitrate salts and $\mathrm{i}-2 \mathrm{M}$ in $\mathrm{HNO}_{3}$. The $\mathrm{Al}\left(\mathrm{NO}_{3}\right)_{3}$ also helps complex any fluoride ions that still may be remaining from the sample preparation.

2. Add $1 \mathrm{~mL}$ of the ${ }^{242} \mathrm{Pu}$ tracer solution to a blank sample of the same matrix and carry through with the sample(s). The plutonium recovery will be determined from this spiked blank sample.

3. Add at least $50 \mathrm{mg} \mathrm{FeSO}_{4}$ and warm the solution for 5 minutes on low heat with stirring. [This reduces $\mathrm{Pu}(\mathrm{V})$ and (VI) to $\mathrm{Pu}(\mathrm{III})$ and (IV)].

4. Add at least $50 \mathrm{mg} \mathrm{NaNO}$ and warm the solution for 2-3 minutes while stirring. [This oxidizes $\mathrm{Pu}(\mathrm{III})$ to $\mathrm{Pu}(\mathrm{IV})$ ]. NOTE: Do not leave the solution at this point: delaying the extraction will allow the oxidation state of the plutonium to change.

5. Cool the solution to room temperature. Extract the plutonium with $5 \mathrm{~mL}$ of 0.3 $M$ tri-n-octyl amine solution [1/2 of the aqueous volume]. Agitate for 2-3 minutes.

6. Separate the aqueous phase and retain the organic phase.

7. Separate uranium and iron from the organic phase by agitating with an equal volume [ $5 \mathrm{~mL}]$ of $0.7 \mathrm{M} \mathrm{HNO}_{3}$. Repeat two more times and discard the aqueous washes.

8. Add $5 \mathrm{~mL}$ [equal the volume of tri-n-octyl amine solution] of 2-ethyl-1-hexanol, or scintillation grade toluene, to the organic phase and mix gently.

9. Strip the organic phase with 7-8 $\mathrm{mL}$ of $1 \mathrm{~N} \mathrm{H}_{2} \mathrm{SO}_{4} / 1 \mathrm{M} \mathrm{Na}_{2} \mathrm{SO}_{4}[3 / 4$ of total organic volume]. Collect the aqueous phase (taking care not to include any of the organic phase) in a Teflon beaker. Repeat 2 more times and combine all strippings in the same Teflon beaker.

10. Take the strip solution in the Teflon beaker and place it on a hot plate. Heat until all boiling stops. Raise the hot plate temperature to $190^{\circ} \mathrm{C}$ and heat for 10 minutes. This will drive off any nitrates that may have been entrained in the sulfuric strip solution. The beaker should contain a dry white powder $\left(\mathrm{NaSO}_{4}\right)$. Any black residue is organic, and must be destroyed by the addition of $\mathrm{H}_{2} \mathrm{O}_{2}$ and nitirc acid and heating again until the white fumes of $\mathrm{SO}_{3}$ appear. Set the beaker aside to cool.

11. Slowly add distilled water to the beaker until the original volume $(-24 \mathrm{~mL})$ has been restored. Transfer this solution to a $50 \mathrm{~mL}$ centrifuge tube. 
12. Add $1.50 \mathrm{~mL}$ of the THOREX extractive scintillator and agitate for 3 to 5 minutes, and centrifuge for 3 to 5 minutes. Draw off $1.00 \mathrm{~mL}$ of the organic scintillator and place it in a $10 \times 75 \mathrm{~mm}$ glass test tube. (A graduated, glass pipet or a highprecision, calibrated pipettor should be used when adding or removing volumes of extractive scintillators.

13. Sparge with toluene-saturated argon gas for $\sim 5$ minutes and then count on the PERALS spectrometer for one hour. Recoveries in excess of $95 \%$ are common.

\section{Data Analysis:}

1. Integrate peaks of ${ }^{238} \mathrm{Pu},{ }^{239 / 240} \mathrm{Pu}, \&{ }^{242} \mathrm{Pu}$.

2. Determine plutonium recovery from ${ }^{242} \mathrm{Pu}$ peak of the spiked sample.

3. Calculate the original activity of ${ }^{238} \mathrm{Pu}$ and ${ }^{239 / 240} \mathrm{Pu}$ in $\mathrm{Bq}$ using the following equation:

$$
\mathrm{Pu}(\mathrm{Bq})=\frac{(\text { GRCNT }-\mathrm{BKG}) \times \mathrm{V}_{\text {OT }}}{\text { TIME } \times \mathrm{V}_{\text {OC }} \times 60 \times \mathrm{R}}
$$

where:

$\mathrm{Pu}=$ plutonium concentration in $\mathrm{Bq}$ for each isotope.

GRCNT = gross count from integration of each plutonium peak of interest.

BKG = background count in same region of interest (normally about 0 ).

$\mathrm{V}_{\mathrm{OT}}=$ total volume of extractive scintillator used, $(1.50 \mathrm{~mL})$.

$\mathrm{V}_{\mathrm{OC}}=$ volume of extractive scintillator counted, $(1.00 \mathrm{~mL})$.

TIME = count time (minutes).

$60=\mathrm{dpm} / \mathrm{Bq}(\mathrm{dpm}=$ disintegrations per minute $)$.

$\mathrm{R}=$ fractional ${ }^{242} \mathrm{Pu}$ recovery.

\section{Lower Limit of Detection:}

Normally, when counting most alpha-emitting isotopes on the PERALS spectrometer, the background counts under the alpha peak of interest is nearly 0 for most reasonable counting times. In such instances, the lower limit of detection (LLD) is calculated based on the probability that as alpha particles will be emitted but not counted. The following equation is used: 


$$
\operatorname{LLD}=\frac{3 \times V_{\text {OT }}}{\text { TIME } \times E F F \times V_{\propto} \times 60 \times R}
$$

where:

LLD $=$ lower limit of detection in Bq.

TMME = count time in minutes.

$\mathrm{EFF}=$ efficiency of the counter $=0.99=99 \%$ for PERALS.

$\mathrm{V}_{\text {Or }}=$ total volume of extractive scintillator used, $(1.50 \mathrm{~mL})$.

$\mathrm{V}_{\propto C}=$ volume of extractive scintillator counted, $(1.00 \mathrm{~mL})$.

$60=\mathrm{dpm} / \mathrm{Bq}(\mathrm{dpm}=$ disintegrations per minute).

$\mathrm{R}=$ fractional ${ }^{242} \mathrm{Pu}$ Recovery.

$3=-\ln (0.05), 0.05=5 \%=$ the probability of the occurrence of zero counts. 


\section{Rapid Extraction of Curium from Gelman $\mathrm{GN} 4^{13}$ Filters}

Introduction: The isotopes of curium are phase transferred to an extractive scintillator after the filter media or Gamble's solution is wet ashed in nitric acid and hydrogen peroxide. After all organic components are destroyed, the $\mathrm{pH}$ of the solution is adjusted to 2.0 and the isotopes of Curium are phase transferred to an extractive scintillator that is $0.4 \mathrm{M}$ in octyl(phenyl)- $N, N$-diisobutyl carbamoylmethylphosphine oxide (CMPO) and counted on the PERALS ${ }^{14}$ spectrometer. The procedure is not specific for curium, as the CMPO will extract other actinides. Other methods should be used when other actinides are known to be present.

\section{Reagents:}

NIST-traceable tracer solution of ${ }^{242} \mathrm{Cm},{ }^{243} \mathrm{Cm}$, or ${ }^{244} \mathrm{Cm}, 0.37 \mathrm{~Bq} / \mathrm{mL}(10 \mathrm{pCi} / \mathrm{mL})$. Curium extractive scintillator, $0.4 \mathrm{M}$ octyl(phenyl)- $\mathrm{N}, \mathrm{N}$-diisobutyl carbamoylmethylphosphine oxide (CMPO).

Nitric acid, reagent grade $\mathrm{HNO}_{3}$, concentrated.

De-ionized water (DI-water), $17.0 \mathrm{MOhms}$.

Sodium hydroxide solution, $3 \mathrm{~N} \mathrm{NaOH}$.

[Dissolve $120 \mathrm{~g} \mathrm{NaOH}$ pellets in $500 \mathrm{~mL}$ DI-water and dilute the solution to $1 \mathrm{~L}$.]

Hydrogen peroxide, reagent grade $\mathrm{H}_{2} \mathrm{O}_{2}, 30 \%$.

Nitrate solution, $3 \mathrm{M}$ in $\mathrm{NO}_{3}^{-}$

[Add $558 \mathrm{~g} \mathrm{Al}\left(\mathrm{NO}_{3}\right)_{3} \cdot 9 \mathrm{H}_{2} \mathrm{O}$ to $500 \mathrm{~mL}$ de-ionized water $\left(\mathrm{DI} \mathrm{H}_{2} \mathrm{O}\right)$. Stir to dissolve, then dilute to $1 \mathrm{~L}$ with $\mathrm{DI}_{2} \mathrm{O}$.]

\section{Procedure:}

1. After wet ashing the filter media or Gamble's solution (see sample preparation procedures), evaporate the sample to near dryness, cool, and dilute the residue to a volume of $20-30 \mathrm{~mL}$ with nitrate solution, $3 \mathrm{M}^{\text {in } \mathrm{NO}_{3}}$.

2. Add $1 \mathrm{~mL}$ of the NIST Cm-tracer solution to a blank sample of the same matrix. Carry this spiked sample through the extraction process with the unknown samples.

3. Slowly increase the $\mathrm{pH}$ to $1.5-2.0$ by the dropwise addition of $3 \mathrm{~N} \mathrm{NaOH}$.

\footnotetext{
${ }^{13}$ Gelman Sciences, Inc., 600 S. Wagner Rd., Ann Arbor, Michigan 48106

${ }^{14}$ ORDELA, Inc., 1009 Alvin Weinberg Dr., Oak Ridge, TN 37830
} 
4. Add $1.50 \mathrm{~mL}$ CMPO extractive scintillator and agitate for 3-4 minutes. (A graduated, glass pipet or a high-precision, calibrated pipettor should be used when adding or removing volumes of extractive scintillators)

5. Allow the phases to separate or centrifuge. Once the phases have separated, pipet $0.70 \mathrm{~mL}$ of the organic phase into a $10 \times 75 \mathrm{~mm}$ test tube.

6. Draw off the residual organic phase in the centrifuge tube and discard to mixed waste. Repeat Step 5 and combine the $0.70 \mathrm{~mL}$ extractive scintillator drawn off with the first organic solution to make $1.40 \mathrm{~mL}$ in the test tube.

7 Sparge the scintillator with toluene-saturated argon gas for 5 minutes.

8. Count for one hour on the PERALS spectrometer.

\section{Data Analysis:}

1. Integrate the alpha peaks of ${ }^{242} \mathrm{Cm}$ and the ${ }^{243 / 244} \mathrm{Cm}$.

2. Determine the curium recovery from the spiked sample (it should be $>95 \%$ if the sample was wet ashed properly).

3. Calculate the original activity of ${ }^{242} \mathrm{Cm}$ and the combined activity of ${ }^{243 / 244} \mathrm{Cm}$ in $\mathrm{Bq}$ using the following equation:

$$
\mathrm{Cm}(\mathrm{Bq})=\frac{(\mathrm{GRCNT}-\mathrm{BKG}) \times \mathrm{V}_{\mathrm{OT}}}{\mathrm{TIME} \times \mathrm{V}_{\mathrm{OC}} \times 60 \times \mathrm{R}}
$$

where:

$\mathrm{Cm}=$ curium activity in $\mathrm{Bq}$ for each isotope.

GRCNT = gross count from integration of each uranium peak of interest.

BKG = background count in same region of interest (normally about 0 ).

$\mathrm{V}_{\mathrm{Or}}=$ total volume of extractive scintillator used, $(3.00 \mathrm{~mL})$.

$\mathrm{V}_{\propto C}=$ volume of extractive scintillator counted, $(1.40 \mathrm{~mL})$.

TIME = count time (minutes).

$60=\mathrm{dpm} / \mathrm{Bq}(\mathrm{dpm}=$ disintegrations per minute).

$\mathbf{R}=$ fractional curium recovery

\section{Lower Limit of Detection:}

Normally, when counting most alpha-emitting isotopes on the PERALS spectrometer, the background count under the alpha peak of interest is nearly 0 for most 
reasonable counting times. In such instances, the lower limit of detection (LLD) is calculated based on the probability that an alpha particle will be emitted but not counted. The following equation is used:

$$
L L D=\frac{3 \times V_{\text {OT }}}{T I M E \times E F F \times V_{\propto C} \times 60 \times R}
$$

where:

LLD $=$ lower limit of detection in Bq.

TIME = count time in minutes.

$\mathrm{EFF}=$ efficiency of the counter $=0.99=99 \%$ for PERALS ${ }^{(}$.

$\mathrm{V}_{\mathrm{OT}}=$ total volume of extractive scintillator used, $(3.00 \mathrm{~mL})$.

$\mathrm{V}_{\mathrm{OC}}=$ volume of extractive scintillator counted, $(1.40 \mathrm{~mL})$.

$60=\mathrm{dpm} / \mathrm{Bq}(\mathrm{dpm}=$ disintegrations per minute).

$\mathrm{R}=$ fractional curium recovery.

$3=-\ln (0.05), 0.05=5 \%=$ the probability of the occurrence of zero counts. 


\section{Rapid Sequential Extraction of Plutonium, Curium, and Uranium from Gelman ${ }^{15}$ GN4 Filters}

Introduction: After the filter medium has been wet ashed (see separate procedure), the evaporated sample is diluted to $\sim 3 \mathrm{~mL}$ with a solution saturated in $\mathrm{Al}\left(\mathrm{NO}_{3}\right)_{3}$ and $1 \mathrm{M}$ in $\mathrm{HNO}_{3}$ for the extraction of the isotopes of plutonium into a tertiary amine nitrate solution in toluene. The trioctylamine (TOA) nitrate is then stripped of any uranium that may have been extracted using 3 washes with $0.7 \mathrm{MHNO}_{3}$. The original aqueous and the three nitric acid washes are combined for the extraction of the isotopes of curium and uranium.

The TOA nitrate is stripped with a sulfuric acid solution, which is heated to dryness to remove any residual nitrates. The isotopes of plutonium are then extracted into the primary amine extractive scintillator $\left(\right.$ THOREX ${ }^{16}$ ), and counted on a PERALS ${ }^{17}$ spectrometer.

The original aqueous phase and the nitric acid washes are then heated to dryness and the volume is increased with a weak $\mathrm{HNO}_{3}$ solution at $\mathrm{pH} 2.5$. The isotopes of curium and uranium are extracted with an extractive scintillator containing CMPO and HDEHP. This sample is then counted on a PERALS spectrometer.

\section{Reagents:}

De-ionized water ( $\mathrm{DI} \mathrm{H}_{2} \mathrm{O}$ ), 17.0 MOhms.

Tri-n-octyl amine solution ( $0.3 \mathrm{M}$ amine in scintillation-grade toluene).

THOREX, extractive scintillator.

An extractive scintillator $0.4 \mathrm{M}$ in octyl(phenyl)- $\mathrm{N}, \mathrm{N}$-diisobutyl

carbamoylmethylphosphine oxide (CMPO), and $0.2 \mathrm{M}$ in bis(2-ethylhexyl) hydrogen phosphate (HDEHP).

2-Ethyl-1-hexanol, reagent grade; or toluene, scintillation grade.

Ferrous sulfate, $\mathrm{FeSO}_{4} \cdot 7 \mathrm{H}_{2} \mathrm{O}$, solid.

Sodium nitrite, $\mathrm{NaNO}_{2}$, solid.

Nitric acid, reagent grade $\mathrm{HNO}_{3}$, concentrated.

Nitric acid, $0.7 \mathrm{M}$ solution.

Nitric Acid, $0.010 \mathrm{M}$ solution ( $\mathrm{pH} 2.0$ ).

Sulfuric acid, reagent grade $\mathrm{H}_{2} \mathrm{SO}_{4}$, concentrated.

Sulfuric acid, $1 \mathrm{~N}$ solution.

Nitrate solution, $3 \mathrm{M}_{\text {in }} \mathrm{NO}_{3}^{-}$

\footnotetext{
${ }^{15}$ Gelman Sciences, Inc., 600 South Wagner Rd., Ann Arbor, MI 48106

${ }^{16}$ ETRAC, Inc., 1009 Alvin Weinberg Drive, Oak Ridge, TN 37830

${ }^{17}$ ORDELLA, Inc., 1009 Alvin Weinberg Drive, Oak Ridge, TN 37830
} 
[Add $558 \mathrm{~g} \mathrm{Al}\left(\mathrm{NO}_{3}\right)_{3} \cdot 9 \mathrm{H}_{2} \mathrm{O}$ to $500 \mathrm{~mL} \mathrm{DI} \mathrm{H}_{2} \mathrm{O}$. Stir to dissolve, then dilute to $1 \mathrm{~L}$ with $\mathrm{DI} \mathrm{H}_{2} \mathrm{O}$.]

Solution of sulfuric acid and sodium sulfate ( $1 \mathrm{~N}$ sulfuric acid/1 $\mathrm{M}$ sodium sulfate).

[Add $142.04 \mathrm{~g}$ of $\mathrm{Na}_{2} \mathrm{SO}_{4}$ to $500 \mathrm{~mL} 1 \mathrm{~N}$ sulfuric acid solution. Stir to dissolve, then dilute to $1 \mathrm{~L}$ with $1 \mathrm{~N} \mathrm{H}_{2} \mathrm{SO}_{4}$.]

Ascorbic acid, reagent grade, solid.

NIST-traceable standards of curium, plutonium, and uranium, $0.37 \mathrm{~Bq} / \mathrm{mL}$ (10 $\mathrm{pCi} / \mathrm{mL}$ ).

\section{Procedure:}

1. Spike a blank breathing zone filter with approximately $0.37 \mathrm{~Bq}(10 \mathrm{pCi})$ each of $\mathrm{U}, \mathrm{Cm}$, and $\mathrm{Pu}$ tracer solutions and carry it through with the rest of the test samples to determine nuclide recoveries.

2. After less than $0.2 \mathrm{~mL}$ of the concentrated $\mathrm{HNO}_{3}$ solution remaining from the filter dissolution remains, dilute the sample to $3 \mathrm{~mL}$ with the nitrate solution $3 \mathrm{M}$ in $\mathrm{Al}\left(\mathrm{NO}_{3}\right)_{3}$ to make the final solution $3 \mathrm{M}$ in nitrate salts, and $1-2 \mathrm{M}$ in $\mathrm{HNO}_{3}$.

3. Add $2 \mathrm{mg}$ of $\mathrm{FeSO}_{4}$ and warm the solution for 5 minutes on low heat. [This reduces $\mathrm{Pu}(\mathrm{V})$ and $(\mathrm{VI})$ to $\mathrm{Pu}(\mathrm{III})$ and (IV)].

4. Add $2 \mathrm{mg} \mathrm{NaNO}_{3}$ and warm the solution for 2 to 3 minutes. [This oxidizes $\mathrm{Pu}(\mathrm{III})$ to $\mathrm{Pu}(\mathrm{IV})$ ]. Note: Do not abandon the solution at this point, as the oxidation state of the Plutonium will change over time.

5. Cool the solution and transfer it to a small separatory funnel. Add $2 \mathrm{~mL}$ of the $0.3 \mathrm{M}$ tri-n-octyl amine solution and agitate for 3 to 5 minutes.

6. Separate and save the aqueous phase in a Teflon beaker.

7. Remove the uranium and iron from the organic by adding $2 \mathrm{~mL}$ of the $0.7 \mathrm{M}$ $\mathrm{HNO}_{3}$ solution to the separatory funnel. Agitate for three minutes. Separate and save the aqueous phase with the original aqueous phase. Repeat the $\mathrm{HNO}_{3}$ wash two additional times, and retain all aqueous washes in the Teflon beaker. The organic phase will now contain only the isotopes of $\mathrm{Pu}$.

8. Adjust the $\mathrm{pH}$ of the aqueous phase to 2.0 with $5 \mathrm{M} \mathrm{NH}_{4} \mathrm{OH}$ or $1 \mathrm{M} \mathrm{HNO}_{3}$, as appropriate.

9. Add $200 \mathrm{mg}$ of ascorbic acid (solid) to reduce the iron and immediately transfer the solution to a $50-\mathrm{mL}$ centrifuge tube. 
10. Add $1.50 \mathrm{~mL}$ of the mixed extractive scintillator. Agitate for 3 to 5 minutes and centrifuge for 3 to 5 minutes. Draw off $0.70 \mathrm{~mL}$ of the extractive scintillator and place it in a $10 \times 75 \mathrm{~mm}$ glass test tube. (A graduated, glass pipet or a highprecision, calibrated pipettor should be used when adding or removing volumes of extractive scintillators.)

11. Draw off the residual organic phase in the centrifuge tube and discard to mixed waste. Repeat Step 10 and combine the $0.70 \mathrm{~mL}$ extractive scintillator drawn off with the first organic solutionto make $1.40 \mathrm{~mL}$ in the test tube.

12. Sparge with toluene-saturated argon and count on the PERALS spectrometer. Two extractions are necessary to ensure that the recovery of the Curium isotopes is $>95 \%$.

13. Return to the TOA nitrate organic solution from Step 7 that still contains the $\mathrm{Pu}$, and add $2 \mathrm{~mL}$ of 2-ethyl-1-hexanol or $2 \mathrm{~mL}$ of scintillation grade toluene to dilute the organic solution.

14. Now strip the Pu from the organic solution by adding $4 \mathrm{~mL}$ of the $1 \mathrm{~N} \mathrm{H}_{2} \mathrm{SO}_{4} / 1$ $\mathrm{M} \mathrm{Na}_{2} \mathrm{SO}_{4}$ solution to the separatory funnel. Agitate for three minutes, and drain the aqueous phase (taking care to entrain none of the organic solution in the strip) to a second Teflon beaker. Repeat two more times and combine all strips in the same Teflon beaker.

15. Place the beaker on a hot plate and evaporate slowly to dryness. Turn up the heat on the hot plate to $190^{\circ} \mathrm{C}$ and heat for ten minutes to ensure that all nitrates have been evaporated. The beaker should contain a dry white powder. Any black residue is organic and must be destroyed by the addition of $\mathrm{H}_{2} \mathrm{O}_{2}$ and nitric acid and heating again until all nitrates have been evaporated. Set the beaker aside to cool.

16. Slowly add $12-15 \mathrm{~mL}$ of distilled water to the beaker and transfer this volume to a $50 \mathrm{~mL}$ centrifuge tube.

17. Add $1.50 \mathrm{~mL}$ of the primary amine extractive scintillator THOREX and agitate for 3 to 5 minutes. Centrifuge for 3 to 5 minutes, and draw off $1.00 \mathrm{~mL}$ of the organic into a $10 \times 75 \mathrm{~mm}$ test tube. Sparge with toluene-saturated argon and count on the PERALS spectrometer.

18. Use the recoveries determined from the spiked sample to determine the isotopic recoveries for the test samples. Recoveries of $>95 \%$ are common for the $\mathrm{Pu}$ (with one THOREX extraction), and $>95 \%$ for the isotopes of $\mathrm{U}$ and $\mathrm{Cm}$ (with 2 extractions of the mixed scintillator). 
Data Analysis:

1. Integrate the alpha peaks of the isotopes of $\mathrm{Pu}, \mathrm{Cm} \& \mathrm{U}$.

2. Determine the recovery of the nuclides from the spiked sample (it should be $>95 \%$ if the sample was wet ashed properly).

3. Calculate the original activity of each identified isotope in $\mathrm{Bq}$ using the following equation:

$$
\mathrm{Cm}, \mathrm{Pu} \text { or } \mathrm{U}(\mathrm{Bq})=\frac{(\mathrm{GRCNT}-\mathrm{BKG}) \times \mathrm{V}_{\mathrm{OT}}}{\text { TIME } \times \mathrm{V}_{\mathrm{OC}} \times 60 \times \mathrm{R}}
$$

where:

$\mathrm{Cm}, \mathrm{Pu}, \mathrm{U}=$ activity in $\mathrm{Bq}$ for each isotope.

GRCNT = gross count from integration of each alpha peak of interest.

BKG $=$ background count in same region of interest (normally about 0 ).

$\mathrm{V}_{\mathrm{Or}}=$ total volume of extractive scintillator used.

$\mathrm{V}_{\propto C}=$ volume of extractive scintillator counted.

TIME $=$ Count time (minutes).

$60=\mathrm{dpm} / \mathrm{Bq}(\mathrm{dpm}=$ disintegrations per minute).

$R=$ fractional isotopic recovery

\section{Lower Limit of Detection:}

Normally, when counting most alpha-emitting isotopes on the PERALS spectrometer, the background count under the alpha peak of interest is nearly 0 for most reasonable counting times. In such instances, the lower limit of detection (LLD) is calculated based on the probability that an alpha particle will be emitted but not counted. The following equation is used:

$$
L L D=\frac{3 \times V_{\text {OT }}}{\operatorname{TIME} \times \mathrm{EFF} \times \mathrm{V}_{\propto \mathrm{C}} \times 60 \times \mathrm{R}}
$$

where:

LLD $=$ lower limit of detection in Bq.

TIME = count time in minutes.

$\mathrm{EFF}=$ efficiency of the counter $=0.99=99 \%$ for PERALS.

$\mathrm{V}_{\text {OT }}=$ total volume of extractive scintillator used.

$\mathrm{V}_{\mathrm{OC}}=$ volume of extractive scintillator counted.

$60=\mathrm{dpm} / \mathrm{Bq}(\mathrm{dpm}=$ disintegrations per minute).

$R=$ fractional isotopic recovery. 
$3=-\ln (0.05), 0.05=5 \%=$ the probability of the occurrence of zero counts.

The LLD is normally below $0.0037 \mathrm{~Bq}$ for a one hour count. 


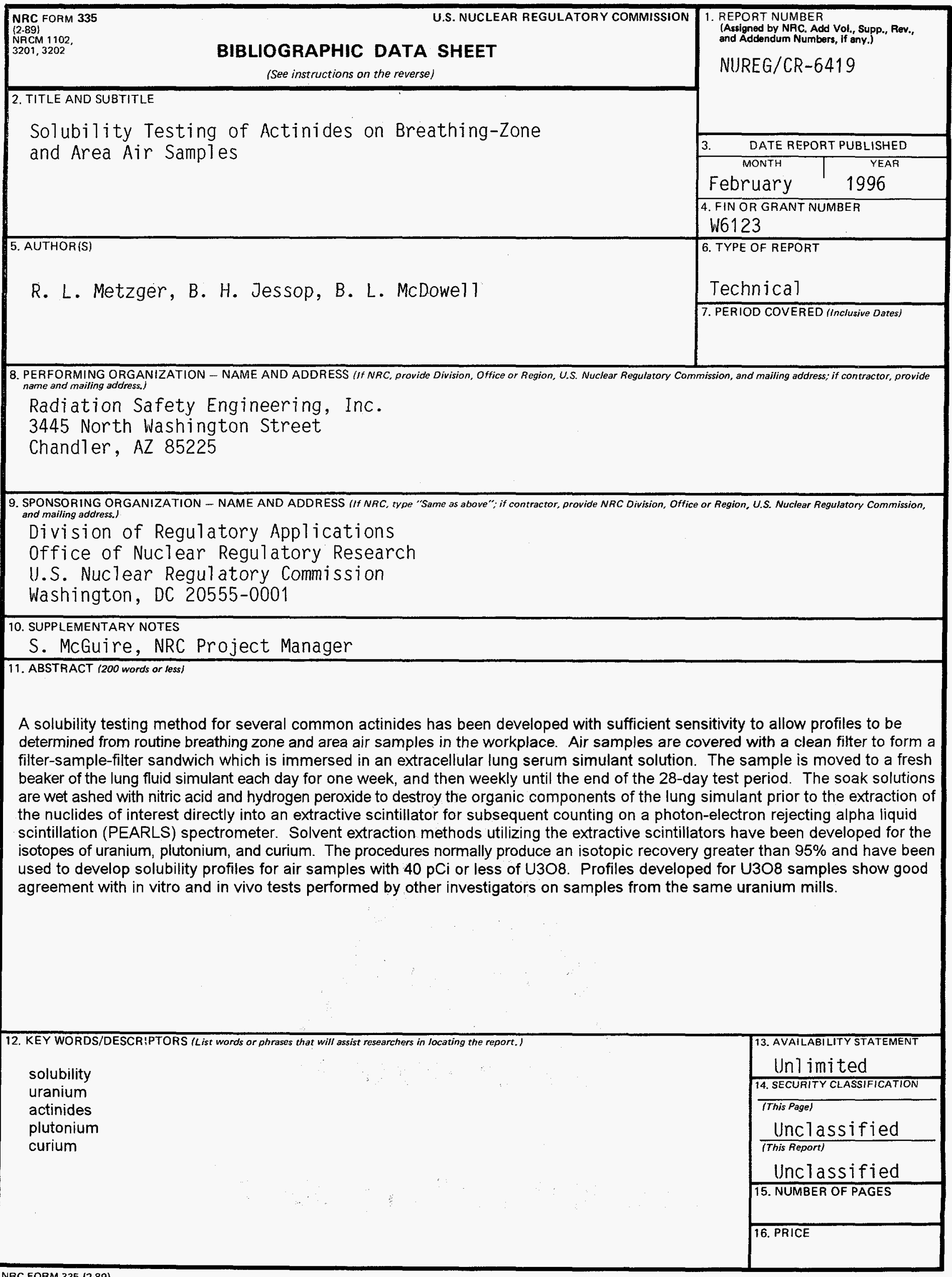

